\title{
First Amendment Doctrine and the Burger Court*
}

\author{
Thomas I. Emerson $\dagger$
}

In the decade since the Burger Court took over from the Warren Court there has been little change in the position that the system of freedom of expression occupies in our national life. Freedom of expression continues to be accepted as the core of our structure of individual rights. It reinains the foundation of our efforts to obtain the proper balance between individual liberty and collective responsibility. And it still provides the framework within which our society tries to achieve necessary, nonviolent, social change.

Throughout this period, political, economic, and social conditions have supported levels of consensus sufficient to inaintaim the system. Indeed, in soine ways political strains on the system have eased as irrational fears of a Communist menace have abated. The material welfare of the country has, at least up to now, continued to expand. And the social climate las not been unduly intolerant or basically hostile to the system. In general, in the last decade the system has not been tested by the strains of crisis conditions.

Nevertheless there have been some significant changes in the system of freedoin of expression. These developments have come about in part because of the natural tendency of any vigorous set of legal doctrines to expand to the limits of their logic. In part the developments are due to technological changes in our society, such as those that have resulted in an ever-increasing concentration of the mass media, in the startling growth of data collection and other pressures on our privacy, and in the alarming probleins associated with the financing of elections. In part the changes are attributable to the inevitable trend of our society toward collectivisin, marked by the dommant role of large organizations, the expansion of governmental functions, and the establisliment of vast public and private bureaucracies. Other changing patterns in our complex society have similarly brought forth new issues.

* For this Article only, textual footnote numbers are placed at the end of paragraphs and all citations appearing in the footnotes proper are placed in the order in which they appear in the footnoted textual paragraph.

$\dagger$ Lines Professor of Law Emeritus, Yale University. B.A. 1928, LL.B. 1931, Yale University. 
This Article will appraise the effects of the Burger Court's decisions on the system of freedom of expression. It will undertake to demonstrate that because of the Court's predilection for ad hoc balancing, its failure to take proper account of the dynamics of suppression, and its unwillingness to develop innovative doctrines in response to changing needs, the system has become less effective at serving its underlying values. Part I will survey developments in the fundamental structure of the system over the past decade. Part II will examine various commentators' proposals for the improvement of basic first amendment doctrine. Against this background, Part III will analyze the application of first amendment doctrine by the Burger Court in tlie various cases that have come before it. Finally, Part IV will evaluate general theoretical approaches to first amendment doctrine.

I

Developments In the Basic Structure of the System OF FREEDOM OF EXPRESSION

The basic structure of the system of freedom of expression, so far as its legal features are concerned, is comprised of three major eleinents. At its root are the fundamental values that the system is intended to serve. Next are the primary instrumentalities charged with mamtaming the system: law and legal institutions. Finally, the system must include some recogmition of the practical problems-the "dynamics"-involved in the actual operation of the system. This recogmition must, of course, be made primarily in the courts when they seek to apply the law to particular problems. Developments in these three areas during the last decade establish the context in which the doctrinal work of the Burger Court must be judged.

\section{A. Underlying Values}

In previous writings I liave attempted to group the traditional values underlying the system of freedom of expression into four categories. Over the years, we have come to view freedom of expression as essential to: (1) imdividual self-fulfillment; (2) the advance of knowledge and the discovery of truth; (3) participation in decisionmaking by all members of society; and (4) maintenance of the proper balance between stability and change.

These values must be considered not in isolation, but as an integrated set. Eacli is necessary, but not in itself sufficient, for the four of them are interdependent. Thus, a system designed to serve only the interest $\mathrm{m}$ orderly change could not succeed in the long run; in a democratic society, such change can only be effected through active partici- 
pation by the polity in decisionmaking. Furthermore, such participation would not be possible without a systemic commitment to the advance of knowledge or the discovery of truth. ${ }^{1}$

It should be remembered, also, that this set of values does not automatically translate into first amendment legal doctrine. The contribution of the law and legal institutions to their achievement can only take place if specific legal rules are formulated to implement the underlying value structure. But that structure does establish the goals we seek, guide the process of creating legal rules, and provide a standard by which the success of those rules can be tested.

During the past decade we have contimued to accept the traditional set of values outlined above as the fundamental basis upon which our system of freedoin of expression rests. Although variations have been suggested, no major changes have been proposed or new values added. There has, however, been considerable discussion, and some elaboration, of the four categories. Most of those who have commented on these matters have been concerned with one specific value, rather than with the whole set. In this respect, particularly because of what they omit, their positions do not conform to that set out above. Nevertheless, the discussion has contributed to our understanding of the value structure. ${ }^{2}$

\section{Individual Self-Fulfillment}

Perhaps the most striking development has been the new emphasis on, and the expansion of, individual self-fulfillment. The late Justice William O. Douglas was one of the leaders in this movement. He imvoked the self-fulfillment value in Griswold v. Connecticut, in which he relied upon the first amendment as a source for the new constitutional right of privacy. He expanded his views im his dissent in Gillette $v$. United States, a conscientious objector case, when he said: "I had assumed that the welfare of the simgle human soul was the ultimate test of the vitality of the First Amendment." And the full range of his vision became clear in Roe $v$. Wade, the abortion case, when he declared that the first amendment was designed to secure "the autonomous control

1. T. EMERSON, THE SYSTEM OF FREEDOM OF EXPRESSION 6-7 (1970) [hereinafter cited as System]; T. EMERSon, TOWARd a General TheORY of THE FIRST AMENDMENT 3-15 (1966) [hereinafter cited as GENERAL THEORY].

2. For a sample of the literature discussing one or more of the values underlying freedoun of expression, see L. TRIBE, American Constirutional LAW 576-79 (1978); Baker, Scope of the First Amendment Freedom of Speech, 25 U.C.L.A. L. Rev. 964 (1978); Blasi, The Checking Value in First Amendment Theory, 1977 AM. B. Found. RESEARCH J. 521; DuVal, Free Communication of Ideas and the Quest for Tnuth: Toward a Teleological Approach to First Amendment Adjudication, 41 GEo. WASH. L. REv. 161 (1972); Karst, Equality as a Central Principie in the First Amendment, 43 U. ChI. L. Rev. 20 (1975); Scanlon, A Theory of Freedom of Expression, 1 PHILosophy \& PUB. AFF. 204 (1972); Wellington, On Freedom of Expression, 88 YALE L.J. 1105 (1979). 
over the development and expression of one's intellect, interests, tastes, and personality."3

The most elaborate exposition of the importance of individual selffulfillment is that of Professor C. Edwin Baker, who advocates a "liberty model" as "the most coherent theory of the first amendment":

The liberty model holds that the free speech clause protects not a marketplace but rather an arena of individual liberty from certain types of governmental restrictions. Speech is protected not as a means to a collective good but because of the value of speech conduct to the individual. The liberty theory justifies protection because of the way the protected conduct fosters mdividual self-realization and self-determination without improperly interfering with the legitimate claims of others. $^{4}$

Professor Laurence $H$. Tribe sounds the same note. He formulates "the central question posed by the Constitution's most majestic guarantee" in the following terms:

[I]s the freedom of speech to be regarded only as a ineans to some further end-like successful self-government, or social stability, or (somewhat less instrumentally) the discovery and dissemination of truth-or is freedom of speech in part also an end in itself, an expression of the sort of society we wish to become and the sort of persons we wish to be? No adequate conception of so basic an element of our fundamental law, it will be argued here, can be developed in purely instrumental or "purposive" terms."

This growing empliasis on the function of the first amendment in protecting individual self-fulfillment reflects an emerging concern with the tendency of modern society to inhibit the growth of the individual personality and the individual's autonomy and self-respect. As such, the expansion of first amendment theory is to be welcomed. It represents an appropriate adaptation of the primciples underlying the first amendment to the modern world.

On the other hand, this development raises some problems. Values that appeal to mdividual, rather than social, interests are often less persuasive to majority elements in a society, particularly where their implementation requires deference to the rights of minorities. This consideration is not a major factor here, however, because the self-fulfillment value is not the sole value involved, but is interlocked with the other three basic, "collective" concerns.

3. Griswold v. Connecticut, 381 U.S. 479, 482-84 (1965); Gillette v. United States, 401 U.S. 437, 469 (1971); Roe v. Wade, 410 U.S. 113, 211 (1973). See also Note, Toward a Constitutional Theory of Individuality: The Privacy Opinions of Justice Douglas, 87 YALE L.J. 1579 (1978).

4. Baker, supra note 2, at $964,966$.

5. Tribe, supra note 2, at 576. See also D. Richards, The Moral Criticism of Law 47 (1977). For a recent nonlegal analysis of freedom of expression in terms of self-fulfillment, see Tinder, Freedom of Expression: The Strange Imperative, 69 YALE REv. 161 (1980). 
More troublesome is the fact that the self-fulfillment value tends to be unconfined. Because that value is arguably implicated in every imaginable type of conduct, it is very difficult to formulate a clear and definite systein to protect it. It is much easier to create and maintain a systein intended to implement the more discernible collective interests. This, however, is a problem of framing legal rules, and does not undermine the value structure itself.

\section{The Advance of Knowledge and the Discovery of Truth}

The second value of freedom of expression-the advanceinent of knowledge and the discovery of truth-has received less attention in the past decade. It should be noted, lowever, that Professor Benjamin $\mathrm{S}$. DuVal, Jr. has rested his version of the system of freedoin of expression exclusively upon one aspect of this value. In his view the only function of freedom of expression that should be considered in defining the content of the first amendment is that it "keeps open the possibility of correcting erroneous beliefs." He explaims:

It is as if the realization of the fallibility of ethical judgment forces any person who desires to act to enter into a pact with the devil. In return for the knowledge that certainty is unobtaimable, and with that knowledge the freedom to act on judgments that may well be erroneous, he must bind himself to leave open the possibility of modification of beliefs. Any act foreclosing modification of beliefs violates the terms of the compact; it is a breach of faith with the guiding principle of uncertainty. ${ }^{6}$

Other writers lave criticized soine of the premises underlying the position that freedom of expression is a means of advancing knowledge or discovering truth. In particular, they have objected to the assumption that people always act rationally. This criticism nay be well taken. It does not, however, diminisli the role of the advancennent of knowledge and the discovery of truth as a basic value behind the first amendment. Although in early discussions of this value the assumption of total rationality was thought to be a necessary premise, it need not be so considered. Instead, one need only assume that rationality is significant in guiding luman behavior. Therefore, the importance of this value to the first amendment remams intact. ${ }^{7}$

\section{Citizen Participation in Decisionmaking}

More significant developments in the value structure have related

6. DuVal, supra note 2, at $206,208$.

7. For a criticism of the behavioral assumptions of the knowledge-truth value, particularly the traditional assumption of the rational formation of beliefs by recipients of the expression, see Baker, supra note 2, at 967-81; DuVal, supra note 2, at 188-94. 
to the function of freedom of expression in assuring citizen participation in public decisionmaking. The views of Dr. Alexander Meiklejohn, who first elaborated the theory that the purpose of the first ainendinent was to protect those areas of communication necessary for a sovereign people to govern themselves, continue to exert great appeal. Variations on the Meiklejohn theme have also been put forward. ${ }^{8}$

To some extent, the emplasis on the decisionmaking function of freedom of expression has resulted in expansion of the foundations of the system. For example, Professor Thomas Scanlon, as well as Baker, places increased empliasis on this function on the ground that the obligation of the individual to comply with community decisions arises only when the community respects individuals as "equal, autonomous, rational agcnts" and that participation in group decisionmaking is essential to that end. While this approach tends to treat the citizen participation value as simply one aspect of the self-fulfillment value, it does give an added dimension to the original concept as formulated by Meiklejohn. It makes relevant an array of considerations not previously taken into account.?

Two other commentators, stressing more immediate considerations, have also expanded the scope of the citizen participation value, and hence have enlarged the coverage of the first amendment. President Edward J. Bloustein of Rutgers has apphied the Meiklejohn analysis to an emerging area of first annendment law: the conflict between freedom of expression and the right of privacy. Using the Meiklejohn approach, Bloustein seeks to draw the hine between the two constitutional rights in terms of the public's "need to know." Professor Vimcent Blasi has developed in substantial detail the function of freedom of expression as a means of checking the abuse of power by public offcials. ${ }^{10}$

On the other hand, some support for the citizen participation value has been designed to have a restrictive effect upon the system of free expression. This occurs where citizen participation is held to be the only value recognized as a basis for constitutional protection of expression, or where citizen participation is narrowly defined. Meiklejohn himself was led by his theory to confine first amendment protection to

8. A. Melkiejohn, Political Freedom (1948). See also Bloustein, The First Amendment and Privacy: The Supreme Court Justice and the Philosopher, 28 RUTGers L. REv. 41 (1974), reprinted in E. Bloustein, Individual and GRoup PrIVACY 41 (1974); Hastie, Free Speech. Contrasting Constitutional Concepts and Their Consequences, 9 HARv. C.R.-C.L. L. REv. 428 (1974); D. Meiklejohn, Public Speech in the Supreme Court Since New York Times v. Sullivan, 26 SYRACUSE L. REV. 819 (1975).

9. Scanlon, supra note 2, at 215-22; Baker, supra note 2, at 990-92. See also D. RrchARDS, supra note 5 , at $45-49$.

10. Bloustein, supra note 8; Blasi, supra note 2. 
expression on "pubhc" matters, thereby excluding communications relating to "private" affairs, although he gave a relatively broad interpretation to the term "public." In recent years, Professor Robert H. Bork has carried this limitmg effort to its furthest point. In Bork's view, the protection of the first amendnient extends only to "political speech," which he defines as speech that deals "explicitly, specifically and directly with politics and government." Indeed, his formulation becomes even narrower when he says, "explicitly and predommantly political speech [is] the only form of speech that a principled judge can prefer to other freedoms." Professor Walter Berns adopts a similarly restrictive position, arguing that the first amendment was intended only to support a "republican" form of government."

The Bork-Berns value system would, of course, sharply curtail the basis for application of the first amendinent. It rejects all other functions of the system, mcluding individual self-fulfillment, and confines protection to speech directly relevant to the governing process. This approach, however, remains a distinctly minority position.

\section{The Balance Between Stability and Change}

The function of freedom of expression in promoting orderly social change has not been stressed in recent literature. Yet it surely remains at the heart of the system. The need for a systen that will facilitate social change-change that will necessarily involve significant deprivations for some members of society and gains for others-has never been more pressing. ${ }^{12}$

All in all the view leeld by our society of the value structure underlying the system of freedom of expression has remained firm. Indeed, to the extent that it has changed, it lias tended to broaden, ratlier than diminish the area of constitutional protection afforded, at least in theory, by the first amendment.

\section{B. The Role of Law and Legal Institutions}

The debate over the role of law and legal institutions im safeguarding a system of freedom of expression goes on. In general, those wlio would limit the goals or coverage of the system would also limit the function of judicial institutions in maintaining it. However, the conclu-

11. A. Meikiejohn, supra note 8; Bork, Neutral Principles and Some First Amendment Problems, 47 IND. L.J. 1, 26 (1971); W. BERNS, THE FiRST AMENDMENT AND THE FUTURE OF AMERICAN DEMOCRACY 186-87 (1976). See also BeVier, The First Amendment and Political Speech: An Inquiry into the Substance and Limits of Principle, 30 STAN. L. REv. 299 (1978).

12. Baker recognizes the social change value, but considers it derivative from his broader "liberty" value, that is, as the right of imdividual citizens to be respected by the collective as "equal, rational and autonomous moral beings." Baker, supra note 2, at 991-92. 
sion that the system needs positive, sympathetic, and aggressive support from the judicial branch of government continues to receive majority acceptance. $^{13}$

\section{The Dynamics of Suppression}

In the past decade nothing has happened to render less crucial a reahistic understanding of the actual operation of the systein of freedom of expression. Experience has confirmed the difficulties and dangers inherent im imposing any kind of government restriction upon expression. Undoubtedly the inost drainatic lessons have coine from Watergate and the recently revealed practices of the FBI, the CIA, and other intelligence agencies in monitoring lawful political activities. These episodes demonstrate how easily government officials may be persuaded that all unorthodox ideas are a danger to the state; how readily an apparatus of files, inforiners, and undercover agents can be assembled; and how quickly the zeal of those committed to the suppression of ideas leading to social change can get out of hand. Fortunately, a serious crisis was averted. These events did, however, vividly bring to pubhic attention the need to formulate legal doctrines that will stand up in periods of tension. ${ }^{14}$

On another level, the importance of devising clear rules of law that will, so far as possible, limit the discretion of lower courts and prosecutors has continued to be manifest. The need to address this problem has been highlighted recently by complamts from members of the press that they have received repressive treatment in the lower courts. Such treatment, they contend, has resulted from Supreme Court decisions concerning restrictions on press coverage of criminal proceedings,

13. For a sampling of the literature, see A. BiCKEL, THE SuPREME COURT AND THE IDEA OF Progress (1970); L. LUSKY, BY What Right? (1975); L. TRIBE, supra note 2, at ch. 1; Ely, The Supreme Court, 1977 Term-Foreword: On Discovering Fundamental Values, 92 HARv. L. REv. 5 (1978); Grey, Do We Have An Unwritten Constitution?, 27 Stan. L. Rev. 703 (1975); Wright, Professor Bickel, The Scholarly Tradition, and the Supreme Court, 84 HARv. L. REv. 769 (1971). Leading opponents of an aggressive judiciary in this area are W. Berns, supra note 11; and BORK, supra note 11.

14. For a summary of these events, see Blasi, supra note 2, at 524-28. The hitany of abuses of authority includes: (1) attempts to intimidate the press during the Watergate affair, see Bazelon, FCC Regulation of the Telecommunications Press, 1975 Duke L.J. 213, 214, 216 n.11; (2) investigations of domestic dissenters by the CIA, and its widespread opening of private letters in the mails; (3) the National Security Agency's monitoring of international telegram and telephone traffic; (4) the FBI's Cointelpro program, involving wiretapping, breaking and entering into private homes and offices, and campaigns of harassunent against disfavored groups and individuals; (5) the Army's infiltration and harassnent of civilian political groups; and (6) the plans to coordmate these activitics on a wider scale, the so-called Huston Plan. See Senate Select Committee to Study Governmental Operations with Respect to InTElligence Activities, Foreign and Military Intelligence-Final Report, S. ReP. No. 755, 94th Cong., 2d Sess. Bk. II, at 10-13, 15-17 (CIA, NSA, and FBI abuses); id. Bk. III, at 800-03, 945-51 (Army activities and Huston Plan). See generally id. Bk. III. 
forced disclosure of confidential sources, probes into the details of editorial decisionmaking, and other aspects of the journalistic process. ${ }^{15}$

Finally, it should be borne in mind that the values underlying the systein of freedom of expression will be served only when all points of view may be expressed. Because the mass media generally give voice to conventional viewpoints, neither they nor those viewpoints often need formal protection. On the other hand, the recently revealed surveillance, infiltration, and harassinent of unorthodox groups by intelligence agencies illustrate once again that minority and unpopular views do need such protection. ${ }^{16}$ Thus, the systein must operate to achieve long term gains for society as a whole at the expense of the immediate interests of the current majorities. Obviously, it is difficult to construct and mamtain a structure of rules and institutions to provide this type of protection.

Very little research or writing has been done on any of these problems in the dynamics of operatimg a systein of freedoin of expression. The issues involved relnain central, however, to the creation of workable legal doctrine. To ignore thein is to render impossible the achievement of a viable system of free expression. ${ }^{17}$

\section{II}

\section{Recent Developments in Basic First Amendment DOCTRINE}

The process of deriving specific legal rules from the value structure contimues to baffie students of the first amendment. Many have tried their hand at it, but no consensus has appeared.

Two fundamental propositions are generally accepted. One is that forms of conduct that implement the set of basic values in a umique way are entitled to special protection under the first amendinent. Such conduct may be designated "expression." There is much disagreement as to what types of conduct fall within this classification, but it is agreed

15. Gannett Co. v. DePasquale, 99 S. Ct. 2898 (1979) (exclusion of press from pretrial hearing); Branzburg v. Hayes, 408 U.S. 665 (1972) (disclosure of confidential sources); Herbert v. Lando, 441 U.S. 153 (1979) (discovery of editorial decisionmaking); Zurcher v. Stanford Daily, 436 U.S. 547 (1978) (police search of newspaper office). An example of a lower court case that the press feels is repressive is Reporters' Comm. for Freedom of the Press v. American Tel. \& Tel. Co., 593 F.2d 1030 (D.C. Cir. 1978), cert. denied, 440 U.S. 949 (1979) (permitting the Bell System to surrender telephone toll call records of reporters to law enforcement officials). For periodic suminaries of the impact of Supreme Court decisions on the press, see REPORTERs' COMMITTEE FOR Freedom of the Press, The News Media and the Law.

16. See note 14 supra.

17. Treatment of some aspects of the dynamics of the system of freedom of expression appear in BeVier, supra note 11, at 322-31, and Monaghan, First Amendment "Due Process," 83 HARv. L. REv. 518, 549-51 (1970). 
that whatever does must be accorded the special protection. This "preferred position" for expression is the startimg poimt for construction of further legal doctrine. Without this basis, a systcm of freedom of expression could not be visualized. ${ }^{18}$

The other proposition is that freedom of expression must be extended to all ideas, no matter how appalling and no matter how hostile to the system. Thus, racist and totalitarian viewpomts are not excluded. On this issue there is a difference of opinion, but the majority clearly loolds to the traditional view. ${ }^{19}$

Beyond this point there is little agreement. Obviously the system of freedom of expression is far too complex to be encompassed in a single legal doctrine. Clearly some areas, suclı as the military, cannot be considered part of the main system at all. Other aspects of the system involve the allocation of scarce pliysical facilities, eitlier between those exercising the right of expression and others, or between several mdividuals or groups eaclı seeking to engage in expression. Freedom of expression for government employees or members of an organization raise particular problems not present when the riglit of the citizen in relation to the wliole community is concerned. It is not possible to deal liere with all these subsidiary issues. Attention must be confined to the basic doctrines that constitute the main imgredients of the system.

Within this limited framework there are two main problems: what forins of conduct are to be considered expression and thereby eligible for protection; and how mucli protection should be given to such expression. The two issues are obviously related. One cannot know what conduct is to be protected without liaving in mind the degree of protection it should be afforded. And the degree of protection afforded will depend upon what is protected. Nevertlieless, for purposes of analysis it is necessary to discuss the two questions separately.

\section{A. Problems of Defining Conduct Protected by the First Amendment}

Most attempts to frame legal doctrine begim with the proposition that the first amendment is applicable to any "expressive activity," or any conduct that "communicates" ideas, inforination, or emotions, whether verbally, physically, or otherwise. Thus Scanlon would apply the first ainendment to "acts of expression" that are intended to com-

18. With respect to the preferred position of expression, see L. TRIBE, supra note 2, at 565; Bork, supra note 11, at 23; Scanlon, supra note 2, at 204; Wellington, supra note 2, at 1105-06.

19. On freedom of expression for racist and totalitarian groups, see L. TRIBE, supro note 2, at 602; DuVal, supra note 2, at 237-42; Scanlon, supra note 2, at 224. For the contrary view, see W. Berns, supra note 11, at ch. 4; R. WolfF, B. Moore, \& H. Marcuse, A Critique of Pure Tolerance (1965); Bork, supra note 11, at 29-35. Cf. A. BiCKel, The Morality of Consent 70-78 (1975); Wellington, supra note 2, at 1126-41. 
municate "some proposition or attitude." Tribe's test is that "conduct that communicates is expression protected by the first amendment." And Professor Melville B. Nimmer argues that the first amendment "protects ideas, not a particular form of expression," and concludes that there need only be a "human" communication. ${ }^{20}$

Baker proposes a somewhat different approach. He attempts to "cut across the communicative, noncommunicative dichotomy" by finding "characterizations of language uses or forms of life that provide msight mto the scope of first amendment protection." He names two such major categories: the "self-expressive" and the "creative." Baker also includes some forms of "action" within the protection of the first amendment. ${ }^{21}$

All of these formulations are, of course, exceedingly vague and, except for Baker's, do not really focus on the problem of what kinds of conduct sliould receive first amendment protection. They leave to otlier doctrimes the question of distinguishing between, for example, writing a book and assassmating a political figure.

In previous writings I have taken the position that the question sliould be resolved by defining "expression" as distmct from other conduct designated "action." Where expression and action are combimed in a single course of conduct, the problem should be to determine which element is predommant. Commentators have almost unaniinously rejected this approach. The reasons for this will be discussed subsequently. Suffice it to say at this point that efforts to define, as precisely as possible, the conduct covered by the first amendment have been largely abandoned. ${ }^{22}$

The result has been to undermine seriously the concept of a "preferred position" for first amendment conduct: when such a vast array of conduct is eligible for some degree of protection, none of it is entitled to "special" protection. Furthermore, this neglect of the question of what conduct is to be covered greatly diminishes the prospects for framing clear rules governing the proper extent of protection.

\section{B. Doctrines Concerning the Proper Degree of Protection for Conduct Covered by the First Amendment}

By failing to define as carefully as possible the conduct covered by the first amendment, inost commentators have necessarily devoted their primcipal attention to issues of what degree of protection the first

20. Scanlon, supra note 2, at 206; L. TRIBE, supra note 2, at 598-601; Nimmer, The Meaning of Symbolic Expression Under the First Amendment, 21 U.C.L.A. L. REv. 29, 33-38 (1972).

21. Baker, supra note 2, at 994, 1009-12.

22. See SySTEM, supra note 1; General TheORY, supra note 1. For citation to criticism of the expression-action dichotomy, see note 124 infra. 
amendment affords "communicative conduct." In general, the very breadth of the concept of "communicative conduct" tends to curtail both the specificity and the degree of protection that will be given. A brief summary of the major doctrines reveals the current state of first amendment theory.

\section{Full Protection}

Since a broad full protection, or "absolute," doctrine is possible only in combination with a relatively precise separation of conduct into "expression" and "action," it is not surprising to find that proposals to hold unconstitutional any law abridging conduct covered by the first amendment are scarce. There are, however, eleinents of the full protection position in unany, perhaps most, comprehensive formulations of first amendment doctrine.

Judge Hans A. Linde argues that clear and present danger or similar exceptions to full protection cannot be utilized by a legislature in enacting legislation, although they may be invoked in the application of a statute where the alleged violation consists of or involves speech. Thus a legislature could not pass a statute outlawing obscene hiterature, but could adopt one punishing a person for contributing to the delinquency of a mimor, which might be violated by making obscene materials available to the minor. Under this system the amount of expression fully protected against government restriction is relatively small since the restriction could always be imposed by way of the application of the statute, usimg expression as evidence of a violation. Nevertheless, Linde does make a strong case for the legal and practical inportance of applymg full protection doctrine to the legislative process. ${ }^{23}$

Tribe proposes an elaborate structure of first amendment doctrine, to be discussed subsequently, that includes a degree of full protection. In Tribe's view, government actions aimed directly at controlling "communicative impact," as opposed to "noncommunicative impact," are "presumptively at odds with the first amendment." The reasons he gives are traditional full protection views:

For if the constitutional guarantee means anything, it means that, ordmarily at least, "government has no power to restrict expression because of its message, its ideas, its subject matter, or its content . .." And if the constitutional guarantee is not to be trivialized, it must mean that government cannot justify restrictions on free expression by reference to the adverse consequences of allowing certam ideas or information to enter the realm of discussion and awareness. Whatever might in theory be said either way, the choice between "the dangers of sup-

23. Linde, "Clear and Present Danger" Reexamined: Dissonance in the Brandenburg Concerto, 22 StaN. L. Rev. 1163 (1970). 
pressing information and the dangers of its misuse if it is freely available" is, ultimately, a choice "that the First Amendinent unakes for us." 24

Tribe then proceeds, however, to qualify his absolute position in major respects. The government restriction is not unconstitutional, he says, if it falls into one of several exceptions, such as preventing a "clear and present danger," compensating for a defamatory falsehood, being justified by a "compelling state interest," and others. Professor John Hart Ely urges a similar view, arguing that expression abridged by government regulations aimed directly at expression, as distinguished from regulations atteinpting to protect an interest unrelated to expression, should automatically be protected without considering the effect of the expression, "subject to a limited exception for deinonstrable falsehoods regarding people or products." Thus both writers feel the need for an absolute rule, but the exceptions they make go far toward swallowing the rule. ${ }^{25}$

The commentator who moves furthest in the direction of full protection, at least potentially, is Scanlon. A philosopher, not a lawyer, Scanlon does not attempt to forunulate specific legal doctrine. His analysis, however, would provide full protection to "acts of expression" under what he calls the Millian Principle:

There are certain harms which, although they would not occur but for certain acts of expression, nonetheless cannot be taken as part of a justification for legal restrictions on these acts. These harms are: (a) harms to certain individuals which consist in their coming to have false beliefs as a result of those acts of expression; (b) harmful consequences of acts performed as a result of those acts of expression, where the conncction between the acts of expression and the subsequent harmful acts consists inerely in the fact that the act of expression led the agents to believe (or increased their tendency to believe) these acts to be worth performing. ${ }^{26}$

This principle, according to Scanlon, is "absolute," providing an "exceptionless restriction on government authority." The position that the government may not restrict expression on the ground that it will cause soineone to believe something is sound. It gives substance to crucial values in the system of freedom of expression by denying the state the right to substitute its judgment on what constitute proper beliefs for

24. L. TRIBE, supra note 2, at 581. The quotations are from Police Dep't v. Mosley, 408 U.S. 92, 95 (1972), and Virginia State Bd. of Pliarmacy v. Virginia Citizens Consumer Council, Inc., 425 U.S. 748,770 (1976).

25. L. TRIBE, supra note 2, at 582, 602, 671-72; Ely, Flag Desecration: A Case Study in the Roles of Categorization and Balancing in First Amendment Analysis, 88 HARv. L. REv. 1482, 1493 n.44.

26. Scanlon, supra note 2, at 213. 
that of the individuals to whom the expression is directed. It also reflects the basic distinction between expression and action.

It is not clear how far Scanlon means to carry this principle, but he apparently gives it a very narrow scope. The first half of the Millian Principle simply protects expression that can have no discernible effect except in the mind of the listener. The second half protects expression that "moves others to act by pointing out what they take to be good reasons for action," even when that action is harmful. This protection seems to cover only the communication of ideas. Scanlon carefully excludes the communication of any information or einotions that would provide the means or impetus for harmful action. Similarly, the Millian Primciple does not protect expression that is itself harmful, whether by impact on a person's reputation, or by direct physical consequence. Accordingly, Scanlon would not object to libel laws or to a ban on sound trucks. Nor would he apply the principle where the government restriction is ostensibly directed at some objective other than speech, as where the government undertakes to forbid all deinonstrations and parades in order to protect traffic, or where the government bans all public meetings of more than ten people because of the probable nuisance to others. Scanlon's theory would test the validity of such restrictions by balancing. ${ }^{27}$

More troublesome are the difficulties of translating Scanlon's Millian Primciple into legal doctrine. There seems to be no practical way to distmguish between harmful action resulting from expression-induced change in belief on the one hand, and liarmful action resulting froin the receipt of information, incitement, or other unprotected communication on the other. In short, the potential of Scanlon's philosophical approach would be difficult to exploit in workable legal doctrine.

Baker and DuVal both adopt full protection positions in theory. Since neither adequately defines the conduct to be protected, however, their theories do not take the form of full protection doctrime in practical application. ${ }^{28}$

In sum, while inost commentators do not wish to abandon the notion of full protection altogether, that approach is applied only in the most obvious cases.

\section{Clear and Present Danger}

The clear and present danger test serves to except froin protection conduct that would otherwise be covered by the first amendment. It reflects a judgment that other societal interests may, under certain cir-

27. Scanlon, supra note 2 , at 215,224 . Wellington gives a much broader interpretation to Scanlon's Millian Principle than I have done here. Wellington, supra note 2, at 1136-38.

28. Baker, supra note 2; DuVal, supra note 2. 
cumstances, outweigh the four basic values underlying the system of freedom of expression. In its original form the test provided that, in the words inade famous by Justice Holmes, "[t]he question in every case is whether the words used are used in such circumstances and are of such a nature as to create a clear and present danger that they will bring about the substantive evils that Congress has a right to prevent." 29

In the past few years the original clear and present danger test has been superseded by a inodified version, first enunciated in Brandenburg v. Ohio:

[T] he constitutional guarantees of free speech and free press do not permit a State to forbid or proscribe advocacy of the use of force or of law violation except where such advocacy is directed to inciting or producing imminent lawless action and is likely to incite or produce such action. ${ }^{30}$

The new formulation retains the requirement that the danger be "clear and present," though it does so through the word "imminent." It adds to the test the element of "incitement," which would seein to limit what nay be proscribed to "advocacy of action" rather than "advocacy of ideas." It is not clear whether the substitution of the tern "lawless action" for "the substantive evils that Congress has a right to prevent" narrows the range of conduct that may be proscribed. On the one hand, "lawless action" inay mean essentially the same thing as the language it replaced, in which case the range of expression that may be restricted reinains unchanged. On the other hand, it may encompass only action that violates existing laws, in which case less expression is subject to regulation. In either event, the new test says nothing about the gravity of the evil sought to be avoided, although that factor may be implied.

The Brandenburg version of the clear and present danger test figures prominently in most attempts to frame first amendment doctrime. The most elaborate justification of the test coines from Staughton Lynd. Finding that it "significantly increases the protection of advocacy," he would apply it not only to cases where "the state seeks to impose criminal sanctions for the advocate's specch," as in the Smith Act cases, but wliere "non-criminal sanctions are imposed," as in cases involving loyalty qualifications for admission to the bar, for government einployment, or for access to the ballot. Lynd would even einploy the test where the government attempts to restrict advocacy in order to protect "the special needs of a government institution," such as a state unversity or the military. In this application Lynd would expand the

29. Schenck v. United States, 249 U.S. 47, 52 (1919).

30. Brandenburg v. Ohio, 395 U.S. 444, 447 (1969). 
term "lawless action" to include violation of institutional rules."

Expansive use of the clear and present danger test has also been urged by Professor Alan E. Fuchs. He argues that expression should receive full protection except "when the acts of expression are likely to have extremely grave consequences and when there is insufficient time between the performances of the actions and the onset of the expected evils either to allow the process of rational discourse to avert the dangers, which would be the most desirable course, or to permit society to prevent independently and directly the harmful consequences." Likewise, as noted above, Tribe makes provision for the clear and present danger test in cases where government suppression is aimed directly at "the communicative impact of expressive activity." Other commentators also endorse it. ${ }^{32}$

The clear and present danger test, as inodified by Brandenburg, clearly protects a greater area of expression than most other tests. This would be particularly true if the test was construed to permit restriction only of conduct that advocates violation of law. Nevertheless, it is still subject to the following serious objections, most of which have been noted elsewhere:

(1) It permits government interference with expression at too early a stage, allowing officials to cut speech off as soon as it shows signs of being effective.

(2) It is an ad hoc test, apphed on each occasion to the circuinstances of the particular case. As such, persons exercising their constitutional right to expression do not know in advance what the limits will be found to be, and are thereby deterred from exercising their rights fully.

(3) The test is excessively vague. It makes the result depend on an official guess as to what the future effects of the expression will be. This is a difficult undertaking for a pohice officer, prosecutor, or court, and is one that could usually yield a determination either way. Brandenburg was a simple case; the defendant advocated action only in tentative terms and to a small group of people who were obviously incapable of undertaking it. If, however, the defendant in Brandenburg had given the same speech on a street corner in the Hough section of Cleveland, the result would not be so clearly dictated by the Court's

31. Lynd, Brandenburg v. Ohio: A Speech Test for All Seasons?, 43 U. CHl. L. REv. I5l, 153, 165 (1975).

32. Fuchs, Further Steps Toward a General Theory of Freedom of Expression, 18 WM. \& MARY L. Rev. 347, 358 (1976) (italics in original); L. TruBE, supra note 2, at 602, 608-17. See Linde, supra note 23; Nimmer, supra note 20, at 42-44, 61-62. See also Gunther, Learned Hand and the Origins of Modern First Amendment Doctrine: Some Fragments of History, 27 STAN. L. REV. 719 (1975). 
formulation. ${ }^{33}$

(4) In some ways the test is imcomplete; it does not take into account the possibility of safeguarding the social interest involved by other means. Furthermore, if it were expanded to include such a factor, it would becoine an ad hoc balancing test. ${ }^{34}$

At best, the clear and present danger test has a relatively limited application. Despite Lynd's efforts to extend the doctrine to the area of pohitical qualifications and institutional settings, it is not fully relevant to those situations. The basis for government refusal to admit persons with disfavored organizational affiliations to the bar, for instance, is not that the "expression" in question will cause a clear and present danger of a violation of law. Rather it is that such affiliations are considered to be evidence of a lack of the qualifications necessary for officers of the courts. Where dissident public employees are discharged, the appropriate question may not be whether the employee's expression advocated violation of an institutional rule, but whether legitimate functions of the organization were seriously prejudiced. The clear and present danger test, in short, has a limited role to play in a comprehensive theory of the first amendment. ${ }^{35}$

\section{Balancing}

Balancing still occupies the dominant position in first amendment doctrine. Some commentators adopt it as a favored technique. Probably most accept it with reluctance, as a last resort. Whatever the attitude, there is little question that most commentators would decide the majority of first amendment cases by balancing. ${ }^{36}$

Discussion of balancing has been thrown into some confusion by the developinent of the concept of "definitional balancing" as distinct from "ad hoc balancing." Nimmer, who first proposed the distinction, argues that ad hoc balancing takes place on the "hiteral level" and is utilized to decide who wins on the particular facts of each case. He

33. Brandenburg, 395 U.S. at $445-47$.

34. For prior criticism of the clear and present danger test, see General Theory, supra note 1, at 51-53. See also DuVal, supra note 2, at 166-71. For an answer to my objections, see Fuchs, supra note 32 , at $368-75$. For a discussion of the objections to ad hoc balancing, see text accompanying notes $38-40$ infra.

35. Compare Law Students Civil Rights Research Council, Inc. v. Wadmond, 401 U.S. 154 (1971), and Konigsberg v. State Bar, 366 U.S. 36 (1961) (bar admission regulations upheld), with Baird v. State Bar, 401 U.S. 1 (1971), and In re Stolar, 401 U.S. 23 (1971) (similar regulations disapproved). The key institutional cases are Parker v. Levy, 417 U.S. 733 (1974) (the Army), and Healy v. James, 408 U.S. 169 (1972) (the university). But cf. Tinker v. Des Momes Indep. School Dist., 393 U.S. 503 (1969) (limiting school disciplinary authority over expression).

36. Balancing figures heavily in the doctrinal structures framed by Scanlon, Tribe, Ely, Bork, Wellington, and Bickel. Balancing is rejected by Baker and DuVal. See also Henkin, Infallibility Under Law: Constitutional Balancing, 78 ColuM. L. Rev. 1022 (1978). 
contrasts this with definitional balancing, which is used to formulate more general rules, such as what forms of conduct are to be regarded as "speech" within the first amendment. Nimmer considers the clear and present danger test to be an example of ad hoc balancing, and the "actual malice" rule enunciated in New York Times $v$. Sullivan to illustrate definitional balancing. ${ }^{37}$

While the traditional criticisins of balancing apply more directly to ad hoc than to definitional balancing, the distinction between the two is of doubtful significance in formulating first ainendment doctrine. Both forms of balancing undertake to weigh the individual and social interests in freedoin of expression against other interests of a different kind, and are therefore subject to the same objections. The real distinction is between all processes that would weigh such interests and those that attempt to define, without balancing, the types of conduct that should receive special protection. According to the latter view, as Justice Black reinarked, the original decision to adopt the first amendinent was the only decision appropriately made by balancing. This original balancing should be taken as final, and legal doctrines should be designed to formulate categories based solely upon the characteristics of the conduct and the value structure underlying the first amendinent. Sorne of the considerations taken into account under such doctrines would be the same as in Nimmer's definitional balancing, but the approach would be fundamentally different. ${ }^{38}$

The principal question for the balancing doctrine is whether any progress has been inade im refining the balancing process. This might be accomplished, in particnlar areas, by creating certain presumptions, giving special weight to certain factors, eliminating certain factors froin consideration, requiring the government to show that other forms of control are not possible, and inaking similar adjustınents in striking the balance. To some extent there has been movement in this direction. Thus Tribe would require greater scrutiny by the court in situations where the government regulation discriminates on the basis of content or operates to deny a public forum. "Coinpelling reasons," burden of proof, and "less drastic means" requireınents liave likewise been advocated. On the whole, lowever, little has been done to alter the existing crudities of the balancing process. ${ }^{39}$

The objections to balancing doctrimes have been stated many times

37. Nimmer, The Right to Speak From Times to Time: First Amendment Theory Applied to Libel and Misapplied to Privacy, 56 CALIF. L. Rev. 935, 942-45 (1968).

38. Justice Black stated his view in his dissent in Konigsberg, 366 U.S. at 61. For a similar statement by Justice Douglas, see his dissent in Branzburg, 408 U.S. at 711.

39. L. TRIBE, supra note 2, at 682-84. See also Shiffrin, Defamatory Non-Media Speech and First Amendment Methodology, 25 U.C.L.A. L. REV. 915 (1978). 
and need not be detailed again here. In essence, the balancing doctrine is no doctrine at all but merely a skeleton structure on which to throw any facts, reasons, or speeulations that may be considered relevant. Not only are there no coinparable units to weigh against each other, but the test is so vague as to yield virtually any result in any case. In the end, balancing extends to expression more a due process than a first amendment type of protection. ${ }^{40}$

\section{III}

\section{ApPlication of First AmENDMENT Doctrine by the BURGER COURT}

The Burger Court inherited a mixed legacy from the Warren Court. In general, the Warren Court protected expression to an unprecedented degree. However, this resulted nore from a strongly favorable attitude toward first amendment values than from a well-developed theory of the first amendment. As a result, the Warren Court's decisions contained numerous ambiguities, loopholes, and loosely formulated rules. Moreover, decisions supporting first amendment claims frequently rested on grounds unrelated to the first amendment. The Burger Court has displayed far less sensitivity to first amendment values than did the Warren Court. On the whole it has refused to press first amendment doctrine forward but rather has tended to withdraw, frequently by taking advantage of openings in Warren Court decisions. The lack of a coherent theory has persisted.

\section{A. The Fundamental Approach}

The Burger Court has fully accepted the traditional set of values underlying the first amendment. It does not often articulate those values, however, and it does not always take them to their logical conclusion. For example, it has not been responsive to the call for development of the self-fulfillment value, as witnessed by its treatment of the long-hair cases. Nor has it been willing to carry the citizen participation value to the point of granting additional access to the facilities for communication. On the other hand, the Court has definitely rejected suggestions that the scope of the first amendment be limited to narrow categories such as "political speech."41

40. See General Theory, supra note 1 , at 53-56.

41. On the Burger Court's acceptance of the traditional values, see, e.g., Cohen v. California, 403 U.S. 15, $24-26$ (1971). On the long hair issue, see Kelley v. Johnson, 425 U.S. 238 (1976). With respect to access, see CBS, Inc. v. Democratic Nat'l Comm., 412 U.S. 94 (1973), and Houchins v. KQED, Inc., 438 U.S. 1 (1978), both discussed infra. On the scope of the first amendment, see, e.g., Southeastern Promotions, Ltd. v. Conrad, 420 U.S. 546 (1975); Virginia State Bd. of Pharmacy, 425 U.S. at 763-65. 
The Burger Court has also adhered to the traditional position that racist and totalitarian expression are entitled to the protection of the first amendment. These issues were dramatically presented in the Skokie case. When a small band of Nazis announced their intention to march in full regahia through the Chicago suburb of Skokie, a village that was the residence of a large number of survivors of the German concentration camps, the village authorities took a series of measures to prevent them. The controversy reached the Supreine Court only on procedural issues and the Court did not have occasion to address the question in detail. But it did make clear that the conduct involved "rights protected by the First Amendment."42

Two other issues of fundamental doctrine deserve more extended discussion. One is the Burger Court's treatment of the "preferred position" doctrine. The other is the question of what conduct is entitled to the special protection of the first amendment.

\section{Preferred Position}

As already noted, the core of first amendment doctrime is that certain conduct, roughly designated "expression," occupies a "preferred position" in our constitutional system. The Warren Court vigorously supported this concept. It was, indeed, at the root of that Court's sympathetic approach toward first amendment rights. The Burger Court has not repudiated the preferred position doctrine. But it has never seemed to accept it wholeheartedly and has frequently ignored it. ${ }^{43}$

Examples of the Burger Court's attitude are numerous. In California v. LaRue, for instance, the Court dealt with regulations that prohibited certain kinds of entertainment in bars or inghtclubs where liquor was served. It conceded that some of the conduct thus proscribed was not obscene, and hence constituted expression within the purview of the first amendment. A majority of the Court, however, upheld the regulation on the ground that the State's conclusion that the regulation was useful in preventing illegal conduct in bars and nightclubs was not "unreasonable" or "irrational." 44

A similar approach guided the Court in Young v. American Mini Theatres, Inc. There a Detroit zoning ordinance imposed severe restrictions upon the location of motion picture theatres that exhibited sexu-

42. National Socialist Party of America v. Village of Skokie, 432 U.S. 43, 44 (1977); Smith v. Collin, 436 U.S. 953 (1978). The Illinois Supreme Court's decision is Village of Skokie v. National Socialist Party of America, 69 Ill. 2d 605, 373 N.E.2d 21 (1978). For a detailed account, see A. Neier, Defending My Enemy (1979).

43. As an example of the Warren Court's approach, see Justice Bremian's opinion in Dombrowski v. Pfister, 380 U.S. 479 (1965).

44. California v. LaRue, 409 U.S. 109, 116, 118 (1972). Justices Douglas, Brennan, and Marshall dissented. 
ally explicit "adult" films. The Court agreed that the films in question were not obscene and hence were expression of a type that the first amendment was intended to protect. Nevertheless, a inajority of the Court upheld the ordinance. Four Justices rested the case on the proposition that "the city's interest in atteinpting to preserve the quality of urban life is one that must be accorded high respect," and that "the city inust be allowed a reasonable opportunity to experiment with solutions to admittedly serious problems." Justice Powell concurred in the decision, saying that there was no "reason to question that the degree of incidental encroachment upon . . . expression was the minimuin necessary to furtlier the purpose of the ordinance." 45

The Burger Court's neglect of the preferred position doctrine is nuanifest in other cases as well. In Lehman v. City of Shaker Heights, the Court was faced with a regulation which, although it allowed the sale of commercial advertising space in the cars of the inunicipal rapid transit system, prohibited the sale of the sane space for political advertisements. A majority of the Court rejected the first amendinent challenge. The plurality opinion of four Justices framed the question as simply whether the policy was "arbitrary, capricious, or invidious," and concluded that the city had advanced "reasonable legislative objectives." In short, the Burger Court betrayed a preference for legislative judgment over first amendment values. ${ }^{46}$

A somewhat different aspect of the preferred position concept arose in Mount Healthy City School District v. Doyle. In this case, a school board refused to rehire a teacher because le had engaged in activities that were found to be only partially protected by the first amendment. The district court found that the protected expression had played a "substantial part" in the scliool board's decision, and ordered the teacher remstated. The Supreme Court remanded the case to the district court to determine whether the board might have reached the same result if it had not taken into consideration the conduct protected by the first amendment. ${ }^{47}$

Similarly, in Houchins v. KQED, Inc., the Court refused to find that the public or the press had any first ainendment right to obtain access to a county jail. And in Gannett Co. v. De Pasquale, the Court held that a trial judge could exclude the public and the press from any criminal pretrial proceeding when he found that their presence would pose a "reasonable probability of prejudice" to the defendant. In these

45. Young v. American Mini Theatres, Inc., 427 U.S. 50, 71, 81-82 (1976). Justices Stewart, Brennan, Marshall, and Blackmun dissented.

46. Lehman v. City of Shaker Heights, 418 U.S. 298, 303, 304 (1974). Justice Douglas concurred on other grounds and Justices Brennan, Stewart, Marshall, and Powell dissented.

47. Mount Healthy City School Dist. Bd. of Educ. v. Doyle, 429 U.S. 274, 283, 287 (1977). 
cases, as well as in Mount Healthy, the Court scarcely displayed a serious effort to give freedom of expression a preferred position. ${ }^{48}$

All of these cases, and others, suggest that where the Burger Court does not favor the type of expression imvolved, where it feels inclined to defer to legislative judgment, or where it prefers another social interest, it does not feel bound by the preferred position doctrine. Its failure to start its analysis in freedoin of expression cases from this doctrinal base , is likely to lead the Court to conclusions that give little effect to first amendment values.

\section{Conduct Covered by the First Amendment}

The Burger Court, like the Warren Court, has rejected all rigorous definitional approaches to the question of what conduct is to be covered by the first amendment, including the "expression-action" approach. It cannot, of course, avoid the question; analysis of a first amendment issue must begin by determining whether the first amendment apphes at all. The Burger Court's approach, in essence, has been to hold that some conduct of a purely verbal nature is outside the purview of the first amendment altogether, that otherwise all conduct having an "expressive" or "communicative" element is covered, and that some kinds of covered conduct are more "pure speech" than others. All of these doctrines were inherited from the Warren Court.

The exclusion of certain conduct that is unquestionably "expression" derives from the famous dictum in Chaplinsky $v$. New Hampshire:

There are certain well-defined and narrowly limited classes of speech, the prevention and punishment of which have never been thought to raise any Constitutional problem. These include the lewd and obscene, the profane, the hbelous, and the insulting or "fighting" words-those which by their very utterance inflict injury or tend to incite an immediate breach of the peace. It has been well observed that such utterances are no essential part of any exposition of ideas, and are of such shight social value as a step to truth that any benefit that inay be derived from them is clearly outweighed by the social interest in order and morality. ${ }^{49}$

The Chaplinsky dictum, although frequently quoted, is totally incompatible with modern first amendment theory. It inakes the exclusions turn on whether the expression has "social value as a step to truth." One of the cardimal principles of first amendment doctrine, however, is that the government nay not base any restriction upon its

48. Houchins, 438 U.S. at 1, Justices Stevens, Brennan, and Powell dissenting, and Justices Marshall and Blackmun not participating; Gannett Co., 99 S. Ct. at 2912, Justices Blackmun, Brennan, White, and Marshall dissenting.

49. Chaplinsky v. New Hampshire, 315 U.S. 568, 571-72 (1942). 
determination that the content of expression is good or bad, or that it has "social value" or does not.

Because of this blatant conflict, there has been some tendency for the Supreme Court to move away from the Chaplinsky doctrine. Thus, in New York Times Co. v. Sullivan the Warren Court removed libel from the Chaplinsky list, and in Cohen v. California the Burger Court in effect took "profane" off the hist. ${ }^{50}$ On the whole, however, that doctrine remains alive. The Burger Court still treats obscenity as expression outside first annendment coverage. Indeed, it has compounded the Chaplinsky error by rejecting the Warren Court's determination that, im order to be "obscene," materials must be "utterly without redeeming social importance." It has instead substituted the less demanding requirement that the material "lacks serious literary, artistic, political, or scientific value." And the "fighting words" exclusion still remams, although the Burger Court has tended less to provide an automatic exclusion from coverage than to determine whether the words would incite to imminent lawless action. ${ }^{51}$

Apart from the Chaplinsky exclusions, the Burger Court contmues to follow the position taken in United States $v$. O'Brien, where the Warren Court held that any "communicative element" in conduct "is sufficient to bring into play the First Amendment." Thus, in Spence v. Washington the Court found that a college student's display of an American flag, upside down and with a peace symbol attached, was conduct "sufficiently imbued with elements of communication to fall within the scope of the First and Fourteenth Amendments."52

At the same time, however, the Burger Court continues the Warren Court's distinction between "pure speech" and other speech. In Landmark Communications, Inc. v. Virginia, dealing with a Virginia statute that prohibited the publication of inforination concerning the confidential proceedings of the State's Judicial Inquiry Commission, the Court made a poimt of the fact that the newspaper involved was engaged in conduct that "lies near the core of the First Amendment." Like the Warren Court, the Burger Court has never enunciated any specific standard for determining the method by which first amendment "core" expression should be protected as compared with other expres-

50. New York Times Co. v. Sullivan, 376 U.S. 254 (1964); Cohen, 403 U.S. at 24-26. See also Plummer v. City of Columbus, 414 U.S. 2 (1973).

51. See Lewis v. City of New Orleans, 415 U.S. 130, 132-33 (1974) (abusive language); Miller v. California, 413 U.S. 15, 24 (1973) (obscenity); Gooding v. Wilson, 405 U.S. 518 (1972) (abusive language); Menoirs v. Massachusetts, 383 U.S. 413, 418 (1966) (obscenity); Roth v. United States, 354 U.S. 476, 484 (1957) (obscenity).

52. United States v. O'Brien, 391 U.S. 367, 376 (1968); Spence v. Washington, 418 U.S. 405, 409-10 (1974) (per curiam). 
sion. $^{53}$

In sum, the Burger Court's approach to determining the coverage of the first amendment has led to ill-considered exclusions and a generally imprecise definition of that coverage. The Chaplinsky exclusions are not related to the functions of the system of freedom of expression. And the concepts of "communicative elements" and "pure speech" are useful only in connection with vague balancing tests.

\section{B. Major Doctrines}

The question of the appropriate degree of protection for conduct covered by the first amendment has been the primary focus of attention for the Burger Court. With the exception of Justices Black and Douglas, the Warren Court did not accept the full protection doctrine and the Burger Court has not departed from this position. Indeed, the loose definition of expression as "communicative" conduct makes full protection or any doctrine approaching it unworkable. Nor does the Burger Court take the position that expression is presuniptively protected unless it falls within some narrowly defined exception. Its main tools for according protection to conduct falling within the ambit of the first amendment are the doctrines of clear and present danger (or some variant), balancing, and prior restraint.

\section{Clear and Present Danger}

In cases involving militant or radical speech that, it is feared, may result in some violation of law, the Burger Court utilizes the Brandenburg version of the clear and present danger test. The Brandenburg case itself dealt with the speech of a $\mathrm{Ku}$ Klux Klan leader who urged a march on Washington to take "revengeance" upon the President, Congress, and the Supreme Court. The Supreme Court, in a per curiam opinion, reversed a conviction under the Ohio Criminal Syndicahism Act, stating that "the constitutional guarantees of free speech and free press do not perimit a State to forbid or proscribe advocacy of the use of force or of law violation except where such advocacy is directed to inciting or producing imminent lawless action and is likely to incite or produce such action." As noted above, the test is a combination of the origmal clear and present danger test, which looked to the potential effect of the speech, and an "incitement" test, which looked to the con-

53. Landmark Communications, Inc. v. Virginia, 435 U.S. 829, 838 (1978); Cox v. Louisiana, 379 U.S. 559, 564 (1965). See also Broadrick v. Oklahoma, 413 U.S. 601, 615 (1973), holding that the overbreadth doctrine applies with less force as the activity moves from "pure speech" to nonspeech conduct; and Bigelow v. Virginia, 421 U.S. 809, 817 (1975), holding that recipients of a communication have greater rights of standing to clrallenge restrictions in "pure speecli" cases. 
tent of the speech. ${ }^{54}$

The Burger Court reaffirmed the Brandenburg test in Hess v. Indi$a n a$, agam in a per curiam opinion, when it reversed a conviction based upon a statement by a leader of a college antiwar demonstration that "We'll take the fucking street later (or again)." The Court has also einployed the test in cases where militant advocacy was not being punished directly but was being used as a disqualification for some governinent benefit or privilege. Thus, in Healy v. James the Court ruled that a state college could not refuse official recognition to a chapter of the Students for a Deinocratic Society on the ground that its advocacy would be "disruptive" unless the advocacy met the Brandenburg standard. And in Communist Party of Indiana v. Whitcomb it applied the Brandenburg test to invalidate an Indiana statute that excluded froin the ballot any party that would not take an oath that it did not "advocate the overthrow of local, state or national government by force or violence." 55

The original clear and present danger test was employed by the Warren Court in Wood v. Georgia and earlier decisions in contempt of court cases, where the expression sought to be punished consisted of vigorous criticism of a court or its persounel. The Burger Court has cited Wood v. Georgia witl approval and would presuinably follow it im a similar situation. Beyond this, lowever, the Burger Court's use of the clear and present danger test has been erratic and confusing. ${ }^{56}$

In Nebraska Press Association v. Stuart, the Burger Court considered the validity of a restraining order issued by a trial judgc in a criminal case enjoining the local media from publishing information about the case that would iniplicate the accused. The Court, speaking througl Chief Justice Burger, resurrected the Hand-Vimson version of the clear and present danger test taken froin Dennis v. United States, namely, "whether the gravity of the 'evil,' discounted by its inuprobability, justifies such mvasion of free speech as is necessary to avoid the danger." This variation of the clear and present danger test had not been utilized by the Supreme Court since its creation in the Dennis case and had been thought to be long dead. Moreover, in applying the test, Chief Justice Burger treated it as a balancing test, including in it a "least drastic means" element:

54. Brandenburg, 395 U.S. at 447.

55. Hess v. Indiana, 414 U.S. 105, 107, 108 (1973), Justices Rehnquist, Blackmun, and Chief Justice Burger dissenting; Healy, 408 U.S. at 188-91; Communist Party v. Whitcomb, 414 U.S. 440, 450 (1974). See also Wadmond, 401 U.S. at 183-84 (Black, J., dissenting); id. at 197 (Marshall, J., dissenting).

56. Wood v. Georgia, 370 U.S. 375 (1962); Landmark Communications, 435 U.S. at 844-45 (out-of-court publicatiou). See also Eaton v. City of Tulsa, 415 U.S. 697 (1974) (where judge failed to caution defendant before citing for coutempt). 
To . . . [apply the test], we must examine the evidence before the trial judge when the order was entered to determine (a) the nature and extent of pretrial news coverage; (b) whether other measures would be likely to mitigate the effects of unrestramed pretrial publicity; and (c) how effectively a restraining order would operate to prevent the threatened danger. The precise terms of the restraining order are also important. We must then consider whether the record supports the entry of a prior restraimt on publication, one of most extraordimary remedies known to our jurisprudence. ${ }^{57}$

The Burger Court also discussed the clear and present danger test in Landmark Communications, Inc. v: Virginia, mentioned above, a case also mvolving the administration of justice. Chief Justice Burger, writing for six inembers of the Court, noted that the Supreme Court of Virginia had relied upon the clear and present danger test in rejecting the first amendment clain1 and stated, "We question the relevance of that standard here." The Court went on, however, to apply the test:

[W]e cannot accept the mechanical application of the test which led that court to its conclusion. . . . Properly applied, the test requires a court to make its own inquiry into the imminence and magnitude of the danger said to flow from the particular utterance and then to balance the character of the evil, as well as its likelihood, against the need for free and unfettered expression. The possibility that other measures will serve the State's interest should also be weighed. ${ }^{58}$

In sum, the Burger Court employs the clear and present danger test only in limited situations. It is used, in its Brandenburg form, in cases concerned with advocacy of illegal action. In cases involving the administration of criminal justice it may or may not be utilized. In other areas it has not been imvoked. Moreover, except possibly in its Brandenburg form, the clear and present danger test has become, in the hands of the Burger Court, pure balancing. Those who hoped for a wider application of the clear and present danger test, or for its use in a "categorical" form, have been disappointed.

\section{Balancing}

The primary test employed by the Burger Court to determine the scope of first amendinent protection is balancing. Indeed, as the number of advocacy cases has declined, the balancing test has come to represent the routine approach of the Burger Court to first amendment issues. The test has not always been apphed in the same way, however, and occasionally it is not used at all.

57. Nebraska Press Ass'n v. Stuart, 427 U.S. 539, 562 (1976); Dennis v. United States, 341 U.S. 494, 510 (1951).

58. Landmark Communications, 435 U.S. at 842-43. Justice Stewart concurred and Justices Brennan and Powell did not participate. 


\section{a. Where the Burger Court Has Used Balancing}

The balancing test has been utilized by the Burger Court in all types of cases. It has frequently been applied where the government restriction takes the form of a direct prohibition or regulation of expression. Thus it lias become the standard test in cases dealing with such matters as the publication of information the government wishes to keep confidential, flag desecration laws, offensive speech, defaination, and limitations on expression in connection with political campaigns. The balancing test is also invoked in cases involving indirect restrictions on expression, where the regulation is ostensibly aimed at soine otler conduct but has a substantial impact upon expression, as in the American Mini Theatres case. It is also applied to situations where special factors call for unconventional rules, as in cases concerned with the rights of government employees or the right of the press to gather news. $^{.9}$

The balancing test is used whetler the opposing interest involved is a constitutional riglit or a nonconstitutional interest. It may function eitler as an ad loc test to decide a particular case or as the basis for developing a more general rule. ${ }^{60}$

What is remarkable about the Burger Court's use of the balancing test is that it is employed even in what appear to be the most obvious cases for uplolding the first amendment claim. Thus, in Landmark Communications, Inc. $v$. Virginia, mentioned above, the Virginia statute in effect established a miniature "official secrets act" that would have imposed a criminal penalty for the publication of any information origmating in a proceeding before the Judicial Inquiry Commission, no matter low the information lad been obtained and no matter how many otliers had already publislied it. It would be hard to find a more blatant violation of the first amendment. Nevertheless, the Court carefully balanced the interests on eacli side. Similarly, in Wooley v. Maynard, the Court dealt with a New Hampshire statute that made it a crime to obscure the words "Live Free or Die" on state license plates. The defendants in the case were Jeliovali's Witnesses who considered the motto repugnant to their inoral, religious, and political beliefs. The

59. Id. at 829 (confidential administrative proceedings); Spence, 418 U.S. at 409 (flag descretion); Erznoznik v. City of Jacksonville, 422 U.S. 205 (1975) (offensive outdoor cinema screen); Gertz v. Robert Welch, Inc., 418 U.S. 323 (1974) (defamation); Buckley v. Valeo, 424 U.S. I (1976) (pohtical campaign regulation); American Mini Theatres, 427 U.S. at 50; United States Civil Serv. Comm'n v. National Ass'n of Letter Carriers, 413 U.S. 548 (1973) (Hatch Act); Branzburg, 408 U.S. at 665 (confidentiality of news sources).

60. See, e.g., Nebraska Press, 427 U.S. 539 (opposing interest constitutional); Gertz, 418 U.S. 323 (opposing interest nonconstitutional); Branzburg, 408 U.S. 665 (four Justices in majority used balancing to formulate the general rule, while Justice Powell concurring and three Justices dissentimg used it on an ad loc basis). 
issue would seem to be a clearcut one of the government forcing unwilling citizens to make an affirmation of belief, a practice long since forbidden by West Virginia State Board of Education v. Barnette, the flag salute case. Yet the Court felt it necessary to weigh the State's "countervailing interest" to see if it justifled the invasion of the right to hold a belief. ${ }^{61}$

Occasionally, however, the Burger Court has declined to use balancing. In Miami Herald Publishing Co. v. Tornillo, the Court was confronted with a Florida statute that required newspapers to publish a reply whenever a political candidate had been attacked in its columns. It unanimously struck down the statute, but did not use balancing language. Rather, as the Warren Court had done in New York Times Co. v. Sullivan, the Burger Court examined the impact of the regulation upon the jourualistic process and found that it imposed a substantial burden. In Linmark Associates v. Willingboro, the Court dealt with a town ordinance, directed at panic selling and white flight to the suburbs, that prohibited the posting of "For Sale" signs on real estate. In another unanimous decision, it held the ordinance invalid. The decision rested in part on balancing doctrine, but was primarily based on what appeared to be a brand of full protection. The town council, said the Court, "has sought to restrict the free flow of these data because it fears that otherwise hoineowners will make decisions inimical to what the Council views as the homeowners' self-interest and the corporate interest of the township."62

\section{b. Variations in the Balancing Process}

The manner in which the Burger Court strikes the balance between first amendinent claims and other interests has varied widely from case to case. In the forn of balancing most favorable to first amendment values, the Burger Court has subjected opposing interests to "exacting scrutiny." For example, in Buckley v. Valeo, where the Court was concerned with limitations on contributions and expenditures in political cainpaigns, it spelled out the exacting scrutiny standard to require that (1) the government demonstrate (2) "a sufficiently important imterest," and (3) employ "ineans closely drawn to avoid unnecessary abridgeinent" of first aniendinent freedoms. Similarly, in First National Bank of Boston v. Belotti, striking down a statute that

61. Landmark Communications, 435 U.S. at 838; Wooley v. Maynard, 430 U.S. 705, 716 (1977); West Virginia State Bd. of Educ. v. Barnette, 319 U.S. 624 (1943).

62. Miami Herald Publishing Co. v. Tornillo, 418 U.S. 241, 256-58 (1974); New York Times Co. v. Sullivan, 376 U.S. 254 (1964); Linmark Assocs. v. Willingboro, 431 U.S. 85, 96 (1977). In Landmark Communications, 435 U.S. at 849, Justice Stewart concurred on full protection rather than balancing grounds. See also Justice Brennan's dissenting opimion in Herbert, 441 U.S. at 180-99. 
forbade corporations to make contributions or expenditures in order to influence the vote in a referendum, the Court agam apphed the "exacting scrutiny" standard, declaring that (1) "the burden is on the Government to show" (2) "a subordmatimg interest which is compelling," and (3) to employ "means closely drawn." The third requirement has been phrased as a straight "less drastic means" test. Although the Court has neyer clearly stated the circumstances under which it will invoke strict scrutiny balancing, this version of the balancing test appears most frequently in cases involving either "political speech" or prior restraints. ${ }^{63}$

At times the Court has tilted the balance less sharply in the direction of the first amendment. For example, in Wooley v. Maynard, the Court looked into whether "the State's countervailing interest is sufficiently compelling." 64

In some decisions, the weighing process has appeared basically neutral; neither the first amendment imterests nor the opposing government imterests enjoyed any presumption. In Landmark Communications, for instance, the Court simply sought to ascertam whether the State's interests were "sufficient to justify the encroachment on first amendment guarantees." In Gertz, it attempted to find an "accommodation" between the interests involved. And in Gannett Co. v. DePasquale, it upheld the exclusion of the public and the press from a pretrial hearing "on an assessinent of the competing societal interests involved." 65

Iromically, the forn of balancing that gives the least protection to first amendment rights was first enunciated by the Warren Court. In United States v. O'Brien, that Court held that the government restriction - a prohibition agamst draft card burning - was vahid if (1) "it furthers an important or substantial governmental interest," (2) the governmental interest is "unrelated to the suppression of free expressions," and (3) "the incidental restriction on alleged first amendment freedoms is no greater than is essential to the furtherance of that imterest." The O'Brien test is hardly balancing at all. Once the government finds a way to direct its regulation at soine conduct other than expression itself-not a difficult task-then it need merely show that the re-

63. Buckley, 424 U.S. at 25; First Nat'l Bank of Boston v. Bellotti, 435 U.S. 765, 786 (1978). For the less drastic means language, see Kusper v. Pontikes, 414 U.S. 51, 59 (1973), See also Smith v. Daily Mail Publishing Co., 99 S. Ct. 2667, 2672 (1979).

For the most stringent formulation of the balancing test, see the opimion of Justice Brennan, voicing the plurality views of three Justices, in Elrod v. Burns, 427 U.S. 347, 362-63 (1976), a formulation with which the dissenters expressed agreement. Id. at 381 .

64. Wooley, 430 U.S. at 716.

65. Landmark Communications, 435 U.S. at 841; Gertz, 418 U.S. at 342; Gannett Co., 99 S. Ct. at 2912. See also Justice Powell's concurring opinion in Gannett, which stated merely that the "coinpeting constitutional interests must be weighed." Id. at 2915. 
striction is no greater than is necessary to further the nonexpression interest. Unless this last requirement is applied as a rigorous "less drastic means" test, which O'Brien does not contemplate, there is virtually no likelihood that the balance will be struck in favor of first amendment values. ${ }^{66}$

The Burger Court, in effect although not explicitly, applied the O'Brien test in Young v. American Mini Theatres, Inc., the Detroit zoning case. The plurality opinion of four Justices, written by Justice Stevens, treated the regulation as primarily a zoning ordmance, directed at improving residential neighborhoods and only incidentally affecting expression. It then balanced inerely to the extent of finding that the "record disclosed a factual basis" for the government's decision. Justice Powell, concurring, expressly applied the $O^{\prime} B r i e n$ test. ${ }^{67}$

\section{c. A Critique of Balancing}

The Burger Court's use of the balancing test demonstrates the vahidity of the objections that consistently have been made to this freewheeling approach to protection of freedom of expression. In nearly every case, the Justices could have struck the balance in favor of either side, and in most cases there was disagreement with the balance that prevailed. Elrod v. Burns, Bellotti, and Herbert v. Lando are ready examples. Furthermore, the Burger Court has made no progress in refining the test by delineating the weight to be given to specific factors. Rather, it has devised a number of variations and has applied them erratically. Equally important, however, is the fact that uninhibited use of the balancing test has led the Burger Court into other positions that are in basic conflict with traditional first amendment theory. ${ }^{68}$

i. Measuring the value of expression. The Burger Court has come more and unore to weigh in the balance its view of the social value of the expression being challenged. Thus in American Mini Theatres, the four Justices subscribing to the plurality opinion expressly took the position that "the stated principle that there may be no restriction whatever on expressive activity because of its content" unust be "sometimes qualified." Pursuant to this position the plurality declared that "there is surely a less vital interest in the uninhibited exhibition of material that is on the borderline between pornography and artistic expression than in the free dissemination of ideas of social and political

66. O'Brien, 391 U.S. at 377.

67. American Mini Theatres, 427 U.S. at 71, 79-82.

68. Elrod, 427 U.S. at 382-88, Chief Justice Burger and Justices Powell and Rehnquist dissenting; Bellotti, 435 U.S. at 804-21, Justices White, Brennan, and Marshall dissenting; Herbert, 441 U.S. at 195-98, 204-06, Justices Brennan and Marshall dissenting. 
significance." It went on to hold that "society's interest in protecting this type of expression is of a wholly different, and lesser, inagnitude than the interest in untrammeled political debate." The attitude of the four Justices toward first ainendinent theory becaine inanifest when the opinion concluded:

Whether political oratory or philosophical discussion moves us to applaud or to despise what is said, every schoolchild can understand why our duty to defend the right to speak remams the same. But few of us would march our sons and daughters off to war to preserve the citizen's right to see "Specified Sexual Activities" exhibitcd in the theaters of our choice. Even though the First Amendment protects commumication in this area from total suppression, we hold that the State may legitimately use the content of these materials as the basis for placing them in a different classification from other motion pictures. ${ }^{69}$

In Federal Communications Commission v. Pacifica Foundation, three of the same Justices formed a plurality that held that the FCC could validly impose sanctions upon a radio station for broadcasting a prograin entitled "Filthy Words," even though the prograin was not obscene and hence should have been protected by the first ainendinent. Again arguing that the rule that "prohibits all governmental regulation that depends on the content of speech" is not "absolute," the Justices found that "offensive" words occupied a low place "in the hierarchy of First Amendnient values."70

Thus the Burger Court is only one vote shy of a majority that expressly takes into account its view of the social value of a particular communication in determining whether or to what extent such expression will be protected under the first amendment. Further, that approacl is implicit im other rulings subscribed to by a clear inajority of the Court. For example, in refusing to extend the "actual inalice" rule to situations where a "private individual" rather than a "public official" or "public figure" clainis to liave been libeled, the Court imcorporated into its balance the proposition that "there is no constitutional value in false stateinents of fact," quoting Chaplinsky to the effect that such utterances "are of sucli slight social value as a step to truth that any benefit that may be derived from thein is clearly outweighed by the social interest in order and morality." Similarly, in limiting the "exacting scrutiny" standard largely to cases involving "political speech," on the ground that such expression "is at the heart of the First Amendment's protection," the Court is clearly making a judgment as to the social value of the expression involved. The same is true in commercial

69. American Mini Theatres, 427 U.S. at 66, 65, 61, 70-71. Chief Justice Burger and Justices White and Rehnquist joined in Justice Stevens' opinion.

70. FCC v. Pacifica Found., 438 U.S. 726, 744, 746 (1978). Justice Stevens was joined by Chief Justice Burger and Justice Rehnquist. 
speech cases where, unlike other forms of expression, "deceptive and misleading" communications can be controlled by the government. ${ }^{71}$

These moves in the direction of weighing the social value of the particular expression for which first aniendment protection is sought inevitably follow from the expanding use of the balancing process. It is very difficult, perhaps impossible, to calculate the social interest in a particular communication without explicitly or implicitly taking into consideration the social value that the balancer attaches to that expression. Yet, under longstanding first aniendincnt theory, this is a judgment the government is not entitled to inake. As the Supreme Court said many years ago, "Wholly neutral futilities, of course, coine under the protection of free speech as fully as do Keats' poems or Donne's sermons." 72

ii. Measuring the degree of impairment. Another aspect of the balancing test is that it considers the degree of infringenent on first amendinent rights and denies protection where the impact of the government regulation, although substantial, is not deeined sufficient. Thus in Gannett Co. v. DePasquale, the Court approved denial of access to a pretrial hearing in part on the ground that the deinal "was not absolute but only tentporary." Likewise in Zurcher v. Stanford Daily the Court, balancing the impact of a search warrant rather than a subpoena in obtaining evidence from newspaper ffies, concluded that "[w]hatever incremental effect there nay be in this regard . . . it does not inake a constitutional difference in our judgment." In American Mini Theatres, again, the plurality of the Court was "not persuaded" that the Detroit ordinance prohibiting movie theaters froin operating in designated areas had "a significant deterrent effect on the exhibition of films protected by the First Amendinent." And in his concurrence Justice Powell downgraded the weight of the first amendinent interest by calling the impact "incidental and minimal." In Elrod v. Burns, three Justices, voting to uphold a patronage systen that resulted in the dismissal of government employees because of their political affiliation, characterized the inpact as a "relatively nodest intrusion on First Amendment interests." 73

It has always been a basic tenet of first ainendinent doctrine that any substantial abridgeinent of first amendment rights-any significant

71. Gertz, 418 U.S. at 340 (libel); Bellotti, 435 U.S. at 776 (political speech). See also Buckley, 424 U.S. at 25 (political speech). On the commercial speech cases, discussed in the text accompanying notes 84-90 infra, see, e.g., Friedman v. Rogers, 440 U.S. 1, 9 (1979).

72. Wimters v. New York, 333 U.S. 507, 528 (1948). For more recent statements, see Stanley v. Georgia, 394 U.S. 557, 564 (1969); Mosley, 408 U.S. at 95-98.

73. Gannett Co., 99 S. Ct. at 2912; Zurcher, 436 U.S. at 566; American Mini Theatres, 427 U.S. at 60, 78; Elrod, 427 U.S. at 389. See also Branzburg, 408 U.S. 665. 
chilling effect-is sufficient to trigger the protection of that constitutional guarantee. The balancing test, particularly as employed by the Burger Court, is chipping away at this basic principle and is thus contributing further to the erosion of freedom of expression's preferred position. ${ }^{74}$

iii. Less restrictive alternatives. A third consequence of the balancing test is that it draws into the balance the question whether alternative means of communication are open to those whose expression is being restricted. Traditional first amendment doctrine has long held that the existence of other channels of commumication cannot be used as a justification for the government to close off the particular means of expression that the speaker or histener has chosen. Until recently the Burger Court has adhered to this doctrine. In the Pacifica case, however, a majority of the Court took another tack. The three adherents to the plurahty opinion argued that "adults who feel the need may purchase tapes and records or go to theatres and nightclubs to hear these words." And the two Justices who jomed to make a majority were even more emphatic: "The Commission's holding does not prevent willing adults from purchasing Carlin's record, from attendimg his performances, or, indeed, from reading the transcript reprinted as an appendix to the Court's opinion." Here agam the balancing test is beginning to undermine hitherto firm first amendment doctrine. ${ }^{75}$

\section{Prior Restraint}

The doctrine forbidding prior restramt is one of the major underpinnings of the system of freedom of expression. Its roots go back to the English censorship laws agamst whicl John Milton protested. It is one of the few principles clearly mcorporated in the first amendment by the drafters. And it has been widely accepted as serving a vital function in mamtaining the right to freedom of expression. The doctrine holds that the government may not, through a system of censorship, by use of a court injunction, or otherwise, prohibit or restrict expression in advance of publication, even though the inaterial publislied may be subject to subsequent punishment. The rationale of the doctrine lies $m$ the fact that, taken as a whole, a system of prior restraint is likely to be far more restrictive of expression than subsequent punishment, at least

74. See, e.g., NAACP v. Alabama, 357 U.S. 449 (1958); Watkins v. United States, 354 U.S. 178 (1957). Compare Talley v. California, 362 U.S. 60, 64-65 (1960) (Black, J.), with id. at 66 (Harlan, J., concurring).

75. For the traditional rule, see, e.g., Schneider v. State, 308 U.S. 147, 163 (1939). For adherence to the rule by the Burger Court, see, e.g., Spence, 418 U.S. at 415 n.11; Southeastern Promotions, 420 U.S. at 556. The quotations from FCC v. Pacifica Found., discussed in text accompanying note 70 supra, appear at 438 U.S. at 750 n.28, 760 . See also id. at 762. 
in the absence of a police state. ${ }^{76}$

The prohibition against prior restraints has always been subject to certain exceptions. In the case that first established the doctrine, Near v. Minnesota, Chief Justice Hughes stated that the rule "is not absolutely unlimited," but that limitations would be found "only in exceptional cases." The Warren Court, in Times Film Corp. v. City of Chicago, inade an exception for inotion picture censorship boards established to screen out "obscene" films. Licensing systems for allocation of scarce physical facilities have also been upheld. Until recently, however, these exceptions had renained restricted to narrowly drawn categories, and, on the whole, were capable of relatively precise application. ${ }^{77}$

\section{a. Ad Hoc Balancing in Prior Restraint Cases}

The Burger Court has recognized the significance of the doctrine of prior restraint and has in fact never sustained a prior restraint that did not fall within one of the specific exceptions just noted. Its handling of prior restraint cases has, however, deprived the exceptions of their categorical nature and has left the prior restraint rule seriously weakened.

The prior restraint doctrine confronted a inajor challenge in $\mathrm{New}$ York Times Co. v. United States, the Pentagon Papers case, during the early days of the Burger Court. The government had sought an injunction against the New York Times, the Washington Post, and other newspapers to restrain the publication of the Pentagon Papers on the ground that publication would cause "grave and irreparable nijury" to the United States. In a six to three vote, accoinpanied by a per curiam opinion, the Court denied the government's request, saying that it had not met the "heavy burden" of justifying a prior restraint. The niore precise positions of the individual Justices were set forth in nine separate opimions. Justices Black and Douglas held to their full protection view: the government possessed no constitutional power to "make laws enjoining publication of current news and abridging freedoni of the press in the name of 'national security.' " Justice Brennan took a similar stance but would have allowed an exception in the area of tactical military operations: "only governmental allegation and proof that pubhication must inevitably, directly and immediately cause the occurrence of an event kindred to imperiling the safety of a transport already at

76. For a recent discussion of the doctrine of prior restraint, citing previous materials, see Litwack, The Doctrine of Prior Restraint, 12 HARv. C.R.-C.L. L. REv. 519 (1977).

77. Near v. Minnesota ex rel. Olson, 283 U.S. 697, 716 (1931); Times Film Corp. v. City of Chicago, 365 U.S. 43 (1961); Cox v. New Hainpshire, 312 U.S. 569 (1941); NBC v. United States, 319 U.S. 190 (1943). 
sea can support even the issuance of an interim restraining order." Justices Stewart and White, recognizing the "concededly extraordinary protection against prior restraints," nevertheless were willing to allow an injunction upon a showing of "direct, immediate, and irreparable dainage to our Nation or its people." Justice Marshall did not reach first ainendinent issues. Chief Justice Burger and Justices Harlan and Blackmun, dissenting, felt that the courts should exercise only an extreinely limited review where the executive had determined that disclosure "would irreparably impair the national security."78

The Burger Court has not had occasion to rule again on the doctrine of prior restraint in a national security case. It seeins a fair assumption froin the Pentagon Papers case, however, that it would not impose any stricter barrier to prior restraint than the requireinent of a showing of "direct, immediate, and irreparable dannage," as urged by Justices Stewart and White. ${ }^{79}$

The other major decision in which the Burger Court has considered the doctrine of prior restraint is Nebraska Press Association v. Stuart. As noted above, that case dealt with a trial court judge's order restraining the local news media from publishing information about the accused in a pending inurder case. Chief Justice Burger, in an opinion with which four other Justices concurred, reviewed earlier prior restraint cases and concluded that " $[t]$ he thread running through all these cases is that prior restraints on speech and publication are the most serious and least tolerable infrimgement on First Amendment rights." $\mathrm{He}$ refused to hold, however, that the "barriers to prior restramt" were "absolute" in a fair trial case. Instead, he applied the Hand-Vimson variation of the clear and present danger test, endimg up with elaborate ad hoc balancing. The conditions laid down by Chief Justice Burger for upholding a prior restraint in a fair trial case are hard to meet, but the facts and circumstances must be examined in each case. Justice Brennan, joined by Justices Stewart and Marshall, adopted an absolute position. They stated that "resort to prior restraints on the freedoin of the press is a constitutionally impermissible method for enforcing" the right to a fair trial. Justice Stevens refrained from fully committing himself to Justice Brennan's view, but was inclined to agree with limi ${ }^{80}$

One further case, involving less portentous issues, illustrates the manner in which the Burger Court has dealt with prior restraint questions. In Organization for a Better Austin v. Keefe, a real estate broker

78. New York Times Co. v. United States, 403 U.S. 713,714 (1971); id. at 718 (Black, J., concurring); id. at 726-27 (Brennan, J., concurring); id. at 730-31 (White, J., concurring); id. at 757 (Harlan, J., dissenting).

79. Id. at $\mathbf{7 3 0}$ (Stewart and White, JJ., concurring).

80. Nebraska Press, 427 U.S. at 559, 561, 572; id. at 617 (Brennan, J., concurring). 
obtained an injunction restraining a neighborhood organization froin distributing leaflets criticizing his "blockbusting" tactics, on the grounds that the organization's activities invaded his privacy and caused him irreparable danage. The Supreme Court labelled the injunction a prior restraint and reversed. Again it balanced, saying the the proponent of the injunction "carries a heavy burden of showing justification for the imposition of such a restraint," and concluded that he had "not met that burden" in this case. ${ }^{81}$

It is clear froin these decisions that the Burger Court does not view the prior restraint doctrine as a prohibition on all prior restraints subject to certain categorical exceptions such as obscene inotion pictures or communications about tactical military operations. Rather, in its view, the doctrine simply creates a "presumption" against the vahidity of the restraint and thereby imposes a "heavy burden" on the government to justify the particular restriction then before the Court.

\section{b. The Doctrinal Effects}

The Burger Court's approach to prior restraints reduces the force of the doctrine in two ways. First, the requirement of ad hoc scrutiny of prior restraints is itself likely to result in a "de facto" prior restraint. For example, in a national security case, the government needs only to file a complaimt alleging that publication of certain information will cause "direct, immediate, and irreparable" harm to national security. The court will then issue an order restraining publication to allow the government to present its case. Hearings and appeals will follow. Justice Brennan pointed out the consequences of this procedure in the Pentagon Papers case:

[I] the Executive Branch seeks judicial aid in preventing publication, it inust inevitably submit the basis upon whicli that aid is sought to scrutiny by the judiciary. And therefore, every restraint issued in this case, whatever its form, lias violated the First Amendment-and not less so because that restraint was justified as necessary to afford the courts an opportumity to examine the claim more thoroughly. ${ }^{82}$

This is exactly what happened when the government sought to enjoin The Progressive inagazine froin publishing an article on the inanufacture of the hydrogen bomb. The Supreme Court refused to order an expedited appeal froin the district court injunction against publication. Although the case was ultimately dismissed by the court of appeals, The Progressive remained under effective prior restraint for nearly seven

81. Organization for a Better Austin v. Keefe, 402 U.S. 415, 419 (1971). See also Healy, 408 U.S. at 184.

82. New York Times Co. v. United States, 403 U.S. at 727 (Brennan, J., concurring). 
months. ${ }^{83}$

Second, and equally important, the Burger Court's approach affords little guidance to the lower courts. In a fair trial case, for imstance, the trial judge must weigh various imponderables in each case. Some of these may be mere speculations about future events. The tendency of a trial judge in such a situation is to avoid the risks of prejudicial publicity through the sacrifice of first amendment interests.

In short, unless the prior restraint doctrine is fornulated as an absolute prohibition, with possible exceptions stated in precise categorical terms, it is of limited value in maintaining a system of freedom of expression. The Burger Court has rejected such a fornulation and has, in effect, made the prior restraint doctrine into an ad hoc balancing test.

\section{Other Doctrines}

It is not possible to discuss here the inanner in which the Burger Court has applied various other first amendunent doctrines. Two matters should be noted, however. One is the reversal of the commercial speech doctrime. The other is the Court's failure to develop new or innovative first aunendment law.

\section{Commercial Speech}

The Supreme Court's original reaction to commercial speech was to exclude it froin the system of freedoin of expression. In Valentine $v$. Chrestensen, the Court held that the distribution of commercial handbills on the streets was not protected by the first amendunent. It confirmed the exclusion of commercial speech several years later in Breard v. Alexandria, upholding an ordinance that regulated door-to-door solicitation for commercial purposes. The precise rationale for the comunercial speech doctrine was never clearly articulated. Nevertheless, the results were clear: the power of government to control false or misleading advertising, to require accuracy in labelling, to close the mails to fraudulent practices, to require truth in marketing securities, and to adopt hundreds of similar regulations was accepted as beyond the reach of the first amendment. ${ }^{84}$

Drawing the line between commercial and noncommercial speech, however, was destined to present difficulties. Thus, in Bigelow v. Virginia, a statute prohibiting the sale or circulation of any publication that encouraged procuring an abortion was used to convict the editor of a newspaper for publishing the advertisement of a New York organiza-

83. United States v. The Progressive, Inc., 467 F. Supp. 990 (W.D. Wis.), request for writ of mandamus den. sub nom. Morland v. Sprecher, 99 S. Ct. 3086, case dismissed, Nos. 79-1428, 79 1664 (7th Cir. Oct. 1, 1979).

84. Valeutine v. Chrestensen, 316 U.S. 52 (1942); Breard v. Alexandria, 341 U.S. 622 (1951). 
tion that offered to arrange low-cost abortions in accredited hospitals and clinics. Similarly, in Virginia State Board of Pharmacy v. Virginia Citizens' Consumer Council, the Court was confronted with a statute that prohibited pharmacists from pubhishing or advertising the price of prescription drugs. Both cases combined elements of commercial speech and political speech. The Burger Court, instead of trying to sort out the different kinds of expression involved, elected to scrap the whole commercial speech doctrine. Pointing out that "society . . . may have a strong interest in the free flow of commercial information," the Court concluded that "commercial speech, like other varieties, is protected" by the first amendment. ${ }^{85}$

Since Bigelow and Virginia State Board, in which the statutes involved were invalidated, the Burger Court has decided a number of commercial speech cases. It has struck down the prohibition against "For Sale" signs in Linmark, invalidated some, but not all, restrictions on advertisimg by attorneys, rejected the attempt in Bellotti to forbid corporations to participate in referenda, and upheld a Texas statute prohibiting the use of a trade name in the practice of optometry. The Court reached these results by applying an ad hoc balancing test. The weighing process has probably been more elaborate and exhaustive than in any other area, and the Justices have often been sharply divided on how the balance should be struck. Moreover, the balance has been tilted in favor of the government regulations and against the first anendment protection. As Justice Powell explained in Ohralik v. Ohio State Bar Association, where ambulance chasing was held not protected by the first amendment:

To require a parity of constitutional protection for commercial and noncommercial speech alike could invite dilution, simply by a leveling process, of the force of the First Amendment's guarantee with respect to the latter kind of speech. Rather than subject the First Amendment to such a devitalization, we instead have afforded commercial speech a limited measure of protection, commensurate with its subordimate position in the scale of First Amendment values, while allowing modes of regulation that might be impermissible in the realm of noncommercial expression. ${ }^{86}$

The Burger Court's abandonment of the commercial speech exclusion does operate to extend the area of conduct protected by the first amendment. For this reason many supporters of liberal free speech

85. Bigelow, 421 U.S. 809; Virginia State Bd. of Pharmacy, 425 U.S. at 764, 770.

86. Linmark, 431 U.S. 85. Compare Bates v. State Bar, 433 U.S. 350 (1977) (lawyer advertising protected), with Ohralik v. Ohio State Bar Ass'n, 436 U.S. 447 (1978), and In re Primus, 436 U.S. 412 (1978) (disciplinary rules upheld). Bellotti, 435 U.S. 765 (corporation political activity); Friedman, 440 U.S. 1. The quotation from Ohralik is in 436 U.S. at 456. See also statement in Friedman, 440 U.S. at 10. 
policies have welcomed the change. There is a serious question, however, whether the gain, if any, is worth the cost.

In the first place, commercial speech has historically been treated on an entirely different basis from all of the other forms of communication that make up the system of freedom of expression. This makes it difficult to integrate commercial speech into the system. The Burger Court itself has realized that it must "act with caution" in moving into "this as yet uncharted area." 87

Secondly, the Supreme Court's origmal intuition was probably sound. It is by no means self-evident that commercial speech will fit into the system of freedom of expression at all. Commercial speech does not promote the underlying values of the system in the saine manner as does other expression. It is true that society has an interest in the flow of commercial information; yet, buying and selling for a profit, whether one considers it more or less important than other activities, probably should be governed by different rules. There is much to be said for the argument advanced by Professor Baker:

The individual uses speech to order and ereate the world in a desired way and as a tool for understanding and communicating about that world in ways which he or she finds important. In fact, the values supported or functions performed by protected speech result from that speech being a nuanifestation of individual freedoin and choice. However, im our present historical setting, commercial speech is not a manifestation of individual freedom or choice; unlike the broad categories of protected speech, commercial speech does not represent an atteinpt to create or affect the world in a way which can be expected to represent anyone's private or personal wishes. Therefore, profit-notivated or commercial speech lacks the crucial cormections with individual liberty and self-realization which exist for speech generally, and which are central to justifications for the constitutional protection of speech, justifications which in turn define the proper scope of protection under the first amendment. ${ }^{88}$

Thirdly, changing the earlier rule poses certaim dangers to the system of freedom of expression. As Justice Powell has acknowledged, the introduction of commercial speech into the system tends to dilute and devitalize first amendment doctrime. It justifies and solidifies full scale ad hoc balancing im a way that is bound to affect the whole structure. Furthermore, it legitimizes types of control over expression that have never been acceptable for the original system. It not only leads to regulation of expression that is false, deceptive, or misleading but, as the

87. Friedman, 440 U.S. at 10 n.9.

88. Baker, Commercial Speech: A Problem in the Theory of Freedom, 62 IowA L. Rev. 1, 3 (1976). For criticism of the new doctrine on other grounds, see Jackson \& Jeffries, Commercial Speech: Economic Due Process and the First Amendment, 65 VA. L. REv. 1 (1979). 
Court said in Virginia State Board, it authorizes the institution of requirements for "additional information, warnings, and disclaimers," and "nnay also make inapphicable the prohibition against prior restramts." 89

Concededly, it is not easy to define commercial speech or distinguish it from noncommercial speech for first amendment purposes. But the task does not seem impossible. Commercial speech is basically speech that deals with the buymg and selling of goods and services for a profit. In the words of the Burger Court, it is speech that does "no more than propose a commercial transaction." The statute in Bigelow imposed controls on expression that clearly went beyond this concept of commercial speech and was properly invahidated under the first amendment. The Virginia State Board statute presented a closer case, but probably should have been relegated to the realms of due process. However one comes out in these two particular cases, separate treatment of commercial speech would seein to better serve the system of freedom of expression than the course taken by the Burger Court. ${ }^{90}$

\section{Innovative Doctrines}

The ultimate test of American judicial institutions, in their role as guardians of our imdividual rights, is whether they respond sensitively to the emerging needs of the time. Our most revered judges and our most honored courts are those that have been able to formulate legal doctrines that apply the guiding primciples of our society to new problems on the frontiers of the law. The Burger Court does not ineet that description. It has failed to develop innovative doctrine that will enable the system of freedom of expression to adjust to the changing conditions of the day. In short, it has been a negative court. The decisions of the Burger Court in two important areas-the right of access to the media and the public's "right to know"-illustrate its unwillingness to adopt a positive approach.

\section{a. Access to Channels of Communication}

It has long been recognized that one of the chief deficiencies of our system of freedom of expression is the increasing concentration of ownership of the means of communication and the inability of diverse poimts of view to gain access to the marketplace of ideas. The problem is a dehicate one since its solution involves some intervention by the government in the operation of the system. The Warren Court recognized the significance of the issue and took tentative steps toward a

89. Virginia State Bd. of Pharmacy, 425 U.S. at 771-72, 772 n.24.

90. The quotation is from Pittsburgh Press Co. v. Pittsburgh Comm'n on Human Relations, 413 U.S. 376,385 (1973). 
solution. In Food Employees Union Local 590 v. Logan Valley Plaza, Inc., the Court ruled that a union had the right to picket in the inall of a privately owned shopping center. It thereby extended the traditional right to use streets, parks, and other public places for first aniendment activities to areas that had becoine the "functional equivalent." In Red Lion Broadcasting Co. v. Federal Communications Commission, the Court upheld the "fairness doctrine" in radio and television broadcasting, declaring that, in a situation where physical facilities are scarce, "[i]t is the right of the public to receive suitable access to social, pohitical, esthetic, noral, and other ideas and experiences." The beginnings of a viable doctrine of "suitable access" were thus formulated.91

The Burger Court lias sounded a definite retreat from the position staked out by the Warren Court. Beginning with Lloyd Corp. v. Tanner and concluding with Hudgens v. National Labor Relations Board, it flatly overruled Logan Valley, holding that exclusion from privately owned property was not state action for purposes of the first amendment. The Court dismissed as "attenuated doctrine" the argument that access to areas sucli as inodern shopping centers is crucial for those who cannot afford the nuass inedia, and that the owner has in effect dedicated his property to public use. The Court's old-fashioned concern with the inviolability of private property overrode its interest in maintaining a vigorous systein of freedoin of expression. ${ }^{92}$

In Miami Herald Publishing Co. v. Tornillo, the Court properly denied access to a mediun of comınunication. It unanimously struck down a state statute that would have conipelled a newspaper to give a political candidate equal space for reply to an attack primted by the paper. Since implementation of such a right of access would surely lead to substantial government interference in the operation of the print niedia, and since no issue of scarce physical facilities was involved, the statute clearly crossed the line of unacceptable government intervention. ${ }^{93}$

By contrast, in Columbia Broadcasting System Inc., v. Democratic National Committee, the Burger Court put a stop to the effort to provide greater access to the electronic inedia, where a shortage of physical facilities exists and where the government is necessarily deeply involved in allocation of the scarce opportunities for communication. In

91. Food Employees Union Local 590 v. Logan Valley Plaza, 1nc., 391 U.S. 308, 325 (1968) (shopping center picketing); Red Lion Broadcasting Co. v. FCC, 395 U.S. 367,390 (1969) (fairness doctrine).

92. Lloyd Corp. v. Tanner, 407 U.S. 551 (1972), Justices Marshall, Douglas, Brennan, and Stewart dissenting; Hudgens v. NLRB, 424 U.S. 507 (1976) (Stewart, J.), Justice White concurring, Justices Marshall and Brennan dissenting, and Justice Steveus not participating. The quotation is from Lloyd, 407 U.S. at 569.

93. Tornillo, 418 U.S. 241. 
that case, a radio station liad refused to sell time for political advertisements although it routinely sold time for commercial advertising. The Court upheld the ruling of the FCC that this absolute ban on political advertising was justified under the Federal Communications Act and that it did not violate the first amendment. Chief Justice Burger, writing for a majority of the Court, based the decision upon the ground that the result of imposing an access rule would not only be "further erosion of the journahistic discretion of broadcasters in the coverage of public issues," but "a transfer of control over the treatment of public issues froin the licensees who are accountable for broadcast performance to private imdividuals who are not." The Court thus not only rejected an opportunity to open up the electroiric media to a broader discussion of public issues but displayed a remarkable lack of faith in a fundamental primciple of first amendment theory: a greater number of speakers better serves the four underlying values. ${ }^{94}$

The Burger Court was also reluctant to press for a right of access in Lehman v. City of Shaker Heights, discussed above. There it allowed a mumicipal transit authority to refuse acceptance of political advertising while furnishing space for commercial advertismg. It drew the line, however, in Southeastern Promotions, Ltd. v. Conrad when a municipal theatre in Chattanooga denied use of its facilities for a showing of the rock inusical "Hair." Here the discrimination based upon content was narrow and blatant, and the Court found it a violation of the rule against prior restraint. ${ }^{95}$

In Buckley v. Valeo, the Burger Court approved a soinewhat different form of the right of access. It upheld the provisions of the Federal Election Campaign Act im which Congress provided for the financing of prcsidential campaigns, includimg primary campaigns, froin general tax revenues. "[T]o use public money to facilitate and enlarge public discussion and participation in the electoral process," the Court said, "furthers, not abridges, pertinent First Amendment values." The basic primciple enunciated by the court is one of immense importance; it supplies the foundation for more general use of public funds to provide greater access to the channels of mass communication. The Court was not impressive, however, in dealing with the collateral issues that inevitably arose from such government support of expression. Under the Act in question, public funds were made available to candidates only on certain conditions, one of which was that the candidate forego raismg funds from other sources. In addition, mimor political parties received different treatment froin major parties, and, im fact, no funds at

94. CBS, Inc. v. Democratic Nat'l Comm., 412 U.S. 94, at 124 (1973). Justices Douglas and Stewart concurred in the judgment, while Justices Brennan and Marshall dissented.

95. Lehman, 418 U.S. 298; Southeastern Promotions, 420 U.S. 546. 
all were granted to parties receiving less than five percent of the total vote. The constitutionality of these provisions is subject to grave doubt, but the Court upheld them without serious discussion of the difficult issues mvolved. ${ }^{96}$

It is true that solution of the access problem will depend as inuch upon legislation as on constitutional adjudication. Yet the courts inust be counted on to develop principles that will achieve government promotion of access without jeopardizing the system. The Burger Court has shown little inclination to perforin such a role.

\section{b. The Right to Know}

Another area of potential growth in first anendinent doctrine is the "right to know." The concept of a right to know embraces both the right to read, to histen, to see, and otherwise to receive communications, and the right to obtain information as a basis for transmitting ideas or facts to others. In most situations the right to know will be protected if the rights of the speaker are protected. Hence the main thrust of the system of freedoin of expression lias always been to secure the right to communicate. Under some circumstances, however, the speaker may be unable or unwilling to protect the right to communicate and thus the right to receive communications becomes the key issue. Moreover, in modern times the right to obtain information, especially information in the possession of the government, has assumed greater significance in serving the value of public participation in decisionmaking. Development of the concept of a right to know has now becoine a matter of substantial importance. ${ }^{97}$

As early as 1965, the Warren Court recognized that the first amendment embodies a constitutional right to know. In Lamont $v$. Postmaster General, it upheld the right of citizens to receive "communist political propaganda" froin abroad without having to notify government authorities that they wished such inail delivered to them. And four years later, in Stanley v. Georgia, the Court declared that "[i]t is now well established that the Constitution protects the right to receive information and ideas." $" 98$

The Burger Court has continued to subscribe to this doctrine. For example, in First National Bank of Boston v. Bellotti, the Court noted that its commercial speech decisions "illustrate that the First Amendinent goes beyond protection of the press and the self-expression of in-

96. Buckley, 424 U.S. at $92-93$.

97. For background on the right to know, see Emerson, Legal Foundations of the Right to Know, 1976 WASH. U.L.Q. 1.

98. Lamont v. Postmaster General, 381 U.S. 301, 303 (1965); Stanley, 394 U.S. at 564. See also Red Lion, 395 U.S. at 390. 
dividuals to prohibit government from limiting the stock of information from which members of the public may draw." It went on to say that "[a] commercial advertisement is protected not so much because it pertains to the seller's busmess as because it furthers the societal interest in the 'free flow of commercial information." " Moreover, in Virginia State Board of Pharmacy v. Virginia Citizens' Consumer Council, the Burger Court went somewhat beyond Warren Court decisions by relying upon right to know doctrime to confer standing upon consumers to challenge a Virginia statute that prohibited pharmacists from publishing their prices. ${ }^{99}$

This acceptance of a constitutional right to know, in the sense of a right to receive communications, is significant. The right to know, however, imphes other, more far-reaching possibilities. The concept potentially extends to the requirement that, under some circumstances at least, members of the public have a right to obtain from the government information necessary to participate intelligently in democratic decisionmaking. Governmental withholding of such information from the public is imconsistent with democratic primciples and imcompatible with first amendment values.

For a tine the Burger Court gave indications that it was ready to implement this crucial aspect of the right to know. In two decisions in 1974-Pell v. Procunier and Saxbe v. Washington Post Co. - the Court dealt with prison regulations that controlled the right of the public and the press to enter the prison and interview prisoners. The majority rejected the claims of the press that journalists had a first amendment right to interview any mmate who was willing to talk to them. But it took paims to make clear im both cases that the regulation under attack did allow substantial access to prisons and that the regulations were not intended to conceal from the public the conditions prevailing in the prisons. Moreover, four Justices expressly recognized that total foreclosure of information about the mside of prisons would violate the flrst amendment. Thus, Justice Powell, concurring in Pell and dissenting in Saxbe, declared that "First Amendment concerns encompass the receipt of information and ideas as well as the right of free expression," and concluded that the "underlying" right is the "right of the public to the information needed to assert ultimate control over the political process." Justice Douglas, dissenting with two other Justices in both cases, took the same view, contending that it was not the right of the journalists that was imvolved "but rather the right of the people, the true sovereign under our constitutional scheme, to govern in an imformed maimer." 100

99. Bellotti, 435 U.S. at 783; Virginia State Bd of Pharmacy, 425 U.S. 748.

100. Pell v. Procunier, 417 U.S. 817, 830 (1974); Saxbe v. Washington Post Co., 417 U.S. 843, 
Any hopes that the Burger Court would broaden the scope of the right to know, however, were dashed by Houchins v. KQED, Inc., decided in 1978. In that case, a broadcasting company had been refused permission to inspect and take photographs of a portion of the county jail where the suicide of a prisoner had apparently occurred and where conditions had been reported to be "shocking and debasing." The district court enjoined the prison authorities from denying the station reasonable access to the jail, and the court of appeals affirmed. The Supreme Court, in a four to three decision, reversed. Chief Justice Burger, joimed by Justices White and Rehnquist, summarily dismissed the station's first amendinent claim: "Neither the First Amendment nor the Fourteenth Amendment mandates a right of access to government information or sources of information within the government's control." Justice Stewart agreed with this holding: "The First and Fourteenth Amendments do not guarantee the pubhic a right of access to information generated or controlled by government, nor do they guarantee the press any basic right of access superior to that of the public generally." Justice Stevens, jomed by Justices Brennan and Powell, dissented. Recognizing that "there are unquestionably occasions when governmental activity may properly be carried out in complete secrecy," they poimted out that $\mathrm{m}$ this case the station was "sinnply seek[ing] an end to petitioner's policy of concealing prison conditions from the public." They concluded that

the probable existence of a constitutional violation rested upon the special importance of allowing a democratic community access to knowledge about how its servants were treating some of its members who have been committed to their custody. An official prison policy of concealing such knowledge from the public by arbitrarily cutting off the flow of information at its source abridges the freedoin of speech and of the press protected by the First and Fourteenth Amendments to the Constitution. ${ }^{101}$

Justices Marshall and Blackınun did not participate in the decision. Justice Blackmun probably would not support substantial expansion of the right to know; he had jomed the inajority in Pell and Saxbe, and clearly did not agree with Justice Powell or Justice Douglas. It seems likely, therefore, that Houchins represents the position of a majority of the Court. In that event, further use of the first amendment to limit government secrecy, or to assure the public or the press access to

848 (1974). Chief Justice Burger and Justices Stewart, White, Blackmun, and Rehnquist constituted the majority; Justices Douglas, Brennan, and Marshall dissented. The quotations are from Saxbe, 417 U.S. at 863, 872 (Powell, J., dissenting) and from Pell, 417 U.S. at $839-40$ (Douglas, J., dissenting).

101. Houchins, 438 U.S. at 19, 15, 16, 34, 35, 38. 
information in the possession of the government, would appear to be precluded. ${ }^{102}$

\section{The Dynamics of the System}

The work of the Warren Court reflected considerable awareness of the reahities of the legal process that the Court was attempting to guide and control. The Warren Court actively undertook to ensure that the legal doctrime it proclaimed at an abstract level was translated into practice at the operating level. In the first amendinent field, as in the criminal justice fleld, the Court sought to understand the context in which the constitutional guarantees functioned and to fashion rules that were administratively workable.

The Burger Court, on the other hand, has paid little attention to the dynamics of the system of freedoin of expression. That Court's lack of reahsm is well illustrated by its 1972 decision in Laird v. Tatum. In that case, a group of civilians brought a class action for declaratory and injunctive relief against the Department of the Army, contending that their first amendment rights had been violated by military authorities who had engaged in extensive surveillance of "lawful and peaceful civilian political activity." Specifically, the plamtiffs alleged that (1) Army Intelligence maintained files on the inembership, ideology, programs, and practices of virtually every activist political group in the country, including groups such as the Southern Christian Leadership Conference, Clergy and Laymen United Agamst the War in Vietnain, the American Civil Liberties Union, Woinen's Strike for Peace, and the National Association for the Advancement of Colored People; (2) the Army used undercover agents to infiltrate these civilian groups and to reach into confidential files of student and other groups; (3) the data it collected were distributed to civilian officials in state, federal, and local governments and to each military and intelligence unit and troop command under the Army's jurisdiction, both in the United States and abroad; and (4) these data were stored in one or more data banks. The Court, by a vote of five to four, dismissed the proceeding for lack of a justiciable claim for rehef. The plaintiffs had alleged only a "subjective chill," said Chief Justice Burger's nuajority opimion, and had not presented a "claim of specific present objective harm or a threat of specific future harm."103

At the time of Laird $v$. Tatum, surveillance of lawful political ac-

102. See also United States v. Richardson, 418 U.S. 166 (1974), holding that a citizen has no standing to deinand information about the CIA budget, despite the provisions of article I, $\S 9$ of the Constitution, requiring that "a regular Statement and Account of the Receipts and Expenditures of all public Money" be published.

103. Laird v. Tatum, 408 U.S. 1, 2, 13-14 (1972). Justices Douglas, Marshall, Brennan, and Stewart dissented. 
tivities, not only by Army Intelligence, but also by FBI, CIA, and other intelligence agencies was rampant throughout the country. To hold that such conduct by the government created only a "subjective chill," not sufficient to bring the first amendment into play, revealed either a total ignorance of or a shocking lack of concern for the actual operation of the system of freedom of expression. Although efforts to challenge this widespread political surveillance had made some headway in the lower courts, Laird v. Tatum put an end to judicial prevention of the practice. ${ }^{104}$

The Burger Court revealed a similar failure to comprehend the practical side of suppression in Zurcher $v$. Stanford Daily. As already noted, the Court sanctioned a pohce raid upon the offices of a newspaper by approving, without any showing of necessity, the use of a search warrant rather than a subpoena to obtain evidence. The majority opinion by Justice White virtually ignored contentions that the use of search warrants in such situations would be physically disruptive, and would therefore impede timely publication; that the fear that materials would be readily available to the government would cause confidential sources of inforination to dry up; that the processing of news would be hindered by the prospect that searches would disclose editorial dehiberations; and that the press would resort to self-censorship to conceal its possession of information of potential mterest to the police. The majority simply said that where first amendment mterests are involved the courts shonld "apply the warrant requirements with particular exactitude," and that this "should afford sufficient protection." Past experience suggests that the likelihood that lower court judges will scrutinize requests for warrants with "particular exactitude" is minimal. The net effect of the Court's decision is to leave the press-especially mimority or unpopular segments - wide open to harrassment by police and prosecutimg officials. The Court seems to have seriously underestimated the potential for governmental repression of critics, particularly in times of stress. ${ }^{105}$

Another example of the Burger Court's mability or refusal to appreciate the actual effect of its decisions upon the system of freedom of expression is found in its handling of defamation cases. In New York Times Co. v. Sullivan, the Warren Court, seeking to fit the ancient law of libel into the structure of the first amendment, held that public offi-

104. For a summary of the litigatiou to limit political surveillance, see N. DORSEN, P. Bender, \& B. Neuborne, Emerson, Haber \& Dorsen's Political and Civil Riohts in the UNITED STATES 311-19 (4th ed. 1976).

105. Zurcher, 436 U.S. at 565. See also Smith v. Maryland, 442 U.S. 735 (1979). Again, as in the right of access, the legislature may be called upon to act where the Court las failed to protect the system of freedom of expression. See, e.g., The Privacy Protection Act of 1979, S. 855 \& S. 1790, 96th Cong., lst Sess. (1979). 
cials could not obtain damages for false statements injurious to their reputation unless they could prove "actual mahce" - that the statement was made "with knowledge that it was false or with reckless disregard of whether it was false or not." The Court's position was based upon a realistic appraisal of the impact that any less protective rule would have upon the function of the press as critic of government. Subsequently, the "actual inalice" rule was extended to "public figures," as distmct from "public officials," and in Rosenbloom v. Metromedia, Inc., five members of the Court would have applied the rule to all matters "of public or general interest." 106

At this point the Burger Court changed directions. In Gertz v. Robert Welch, Inc., it limited the "actual malice" rule to public officials and public figures and began to interpret the term "public figures" very narrowly. By the time of Wolston v. Reader's Digest Association, in 1979 , it liad reached the point of declaring that a person who had failed to appear before a grand jury investigating espionage, and was thereby cited for contempt, was not a "public figure." Moreover, in Herbert $v$. Lando, the Court held that a public official or public figure seeking to prove "actual malice" could inquire into the mental states and editorial processes of those responsible for the publication. ${ }^{107}$

The result of these decisions has been to make the press, and indeed all writers or speakers, much more vulnerable to libel suits. Not only is the "actual mahice" rule unavailable in many situations involving inatters of public interest, but even where it is applicable, the decision in Herbert $v$. Lando allows the plaintiff to engage in exhaustive discovery proceedings. Since the cost of defending a libel suit may be as inhibiting as possible liability, the net outcome is not the "uninhibited, robust, and wide-open" debate that New York Times Co. v. Sullivan contemplated, but an unhealthy degree of self-censorship. ${ }^{108}$

In addition to its failure to comprehend the real impact of its decisions, the Burger Court has done little to develop doctrines that are administratively workable. In many cases this is most easily explained as a result of the Court's penchant for ad hoc balancing. For example, in "fair trial" cases, the balancing required by Nebraska Press Association assures that the right of the press to report judicial proceedings will always remain uncertain, and appeals may not solve but may instead compound the problem. Similarly, the decision in Branzburg $v$. Hayes, making the obligation of a reporter to disclose information ob-

106. New York Times Co. v. Sullivan, 376 U.S. at 280; Rosenbloom v. Metromedia, Inc., 403 U.S. 29 (1971) (discussing prior cases).

107. Gertz, 418 U.S. 323; Wolston v. Reader's Digest Ass'n, 99 S. Ct. 2701 (1979); Herbert, 441 U.S. 153.

108. New York Times Co. v. Sullivan, 376 U.S. at 270. 
tained in confidence dependent on a ruling in each case, renders it difficult or impossible for the reporter ever to pledge confidentiality in advance. And in obscenity cases, the rule in Miller $v$. California that the question whether material is obscene or not turns on "community standards" not only imcreases uncertainty and limits appellate review, but tends to force publishers seeking a national market to adhere to the strictest local standard. ${ }^{109}$

The unadministrable rule that Mount Healthy City School District v. Doyle promulgated for institutional employee discharges, however, flows from a nnore basic flaw in the Court's approach. That case holds that a dismissal resting in part upon first amendment activities may nevertheless be sustained if the adjudicatory tribunal finds that it would have occurred anyway. This places a heavy burden on one deprived of first amendment rights to obtain any effective remedy. Unlike the other examples, the uncertainty here results directly from the Court's failure to recognize the preferred position of freedom of expression. ${ }^{110}$

On occasion the Burger Court has been responsive to the underlying realities involved in protecting freedom of expression. For instance, in Miami Herald Publishing Co. v. Tornillo, striking down a state right of reply statute, it took an approach similar to that in New York Times Co. v. Sullivan, looked into the impact of the regulation upon the editorial process, and appraised its effect upon the functioning of the press. On the whole, however, the Burger Court has neglected to take into account the dynamics of a system of freedom of expression. ${ }^{111}$

\section{IV}

\section{ApProaches to First AMENDMENT Doctrine}

The general development of first amendment doctrine and the work of the Burger Court have failed to produce satisfactory legal foundations for an effective system of freedom of expression. Professors Tribe and Baker, however, have made significant efforts to fill this doctrinal need. It remains first to consider their contributions and then to reappraise the full protection position.

\section{A. Professor Tribe's Doctrinal Structure}

Professor Tribe has given us the most elaborate formulation of first

109. Nebraska Press Ass'n, 427 U.S. 539; Branzburg, 408 U.S. 665; Miller v. California, 413 U.S. 15.

110. Mt. Healthy, 429 U.S. 274. See also Givhan v. Western Line Consol. School Dist., 439 U.S. 410 (1979).

111. Tornillo, 418 U.S. 241. See also Justice Harlan's opinion for the Court in Cohen, 403 U.S. at 24-26. 
amendment doctrine proposed in the last decade. He starts from the traditional value structure set forth above, although he places particular emphasis on the self-fulfillment function of freedom of expression. As previously noted, Tribe rejects the expression-action approach and takes as his definition of conduct covered by the first amendment all "conduct that communicates"-all "expressive activity." He then divides the field into two sectors: (1) government actions "aimed at [the] commumicative impact" of expressive activity; and (2) government actions "aimed at noncommunicative impact but nonetheless having adverse effects on communicative opportunity." In the first situation his analysis proceeds along lines he designates as "track one"; in the second situation analysis proceeds on "track two." Track one encompasses such problems as official attempts to suppress advocacy critical of the government or restrictions on advertising the prices of over-thecounter drugs. Track two problems are illustrated by a ban on the distribution of hand bills im order to combat hitter or a regulation against noisy picketing im a hospital area. Restrictions ostensibly directed at noncommunicative conduct but actually motivated by a desire to restrict expressive activity are treated as being on track one. ${ }^{112}$

Track one restrictions are "presumptively at odds with the first amendment." The exceptions to this presumption, however, are extensive. One overarching exception is made for restrictions that are "compellingly justified." The other exceptions are framed as "categorical rules"- "narrowly drawn categorical definitions" of types of expression that are not protected "on the theory that such unprotected expression falls outside the first amendment's purposes or fails to satisfy its premises." These categorical exceptions include fighting words, defamation, expression that invades some aspects of privacy, some commercial speech, and, of course, advocacy that creates a clear and present danger of lawless action. They do not include obscenity. Tribe contends that expression that falls imto any of these excepted categories may be restricted without doing violence to first amendment values. ${ }^{113}$

Track two abridgements of expression are resolved by ad hoc balancing:

On that track, a regulation is constitutional, even as applied to expressive conduct, so long as it does not unduly constrict the flow of information and ideas. On track two, the "balance" between the valucs of freedom of expression and the government's regulatory interests is struck on a case-by-case basis, guided by whatever unifying principles

112. L. TRIBE, supra note 2, at 580-601. Tribe's colleague, Professor Ely, adopts a similar approach and comes out with much the same result. See Ely, supra note 25.

113. L. TRIBE, supra note 2 , at $581,602-82$. 
may be found in past decisions. ${ }^{114}$

Tribe does make an effort to refine the balancing process somewhat. He first identifies more particularly the issue to be resolved: whether the restriction "leaves too little breathing space for communicative activity, or leaves people with too little access to the channels of communication." He then suggests different levels of justification that inay be required for different types of restrictions. In cases involving access to a public forum, the government must show that the restriction achieves an "important public objective" that would be sacrificed by "any less restrictive alternative." In such cases the speaker or histener need not show that alternatives for expression are available. In cases not involving access to a public forum, "the government's burden of justification is minimal"; the restriction need only be "rational." This rule is subject to an exception if the inhibition is "substantial," but it is never "substantial" if the speaker or listener has other alternatives." 15

Tribe's proposals are open to the following serious criticisms:

(1) The structure is so loose and unconfined that it gives only a weak and uncertain protection to freedom of expression. The exceptions in track one, particularly the exception for "compellingly justifiable" restrictions, and the virtually uncontrolled balancing process of track two, are wide open and impose few specific restraints on govcrnmental action. A more solid structure is necessary if it is to protect the systenı of freedom of expression against majoritarian pressures, particularly in periods of stress.

(2) The distinction made between track one and track two does not seem sound or helpful, particularly as a basis for giving only due process protections against most track two restrictions. Virtually all governmental controls of expression are directed, not at the expression itself, but at the harm thought to result from engaging in it. Thus, restrictions on publications critical of the state are designed to promote government efficiency, just as anti-leafletting statutes are designed to prevent litter. The significant inquiry is not into the ostensible objective of the government regulation, but into the effect the regulation will have on the systen 1 of freedom of expression. And the guiding primciple, required by the "preferred position" of expression, is that the government may not seek to achieve other social interests by abridging expression. Hence the fact that the regulation is addressed to "noncommunicative" conduct is not the decisive issue. 116

114. Id. at 582.

115. Id. at $682-93$.

116. Ely, supra note 25 , at 1496-1502, recognizes that restrictions on expression are rarely directed against speech as such but at "some danger beyond the message." Id. at 1496. He then undertakes to distinguish between track one and track two by looking to the "causal connection 
It is not surprising that, as one looks into actual problems, the distinction between track one and track two tends to break down. Thus, Tribe states that libel laws allowing "private" individuals (as distinct from public officials and figures) to recover damages for defamation could be considered as track two restrictions. Likewise, as Tribe acknowledges, the Detroit ordinance involved in Young v. American Mini Theatres, Inc., which severely restricted the locations of theatres slowing "adult" movies in the interest of "better neighborhoods" can be considered as falling within either track one or track two. Soine track two restrictions can be transposed into track one by showing a legislative notive to deal with the impact of communicative activity; but legislative motive, as United States v. O'Brien (the draft card burning case) demonstrates, is a chancy thing to prove. And the actual impact of the restriction on the systein of freedonn of expression is not necessarily affected by legislative motive. ${ }^{17}$

Even if the distinction between track one and track two restrictions were relevant to first amendment problems, no satisfactory reason lias been advanced for giving the expression curtailed by track two restrictions only "minimal," or "due process," rather than "preferred," protection. The existence of such restrictions is widespread and increasing; their effect upon the system inay be at least as serious as track one restrictions.

(3) The "categorical rules" are really not "narrowly drawn categorical definitions," and in some cases are not based on sound first amendment theory. The clear and present danger test, for exaunple, at least insofar as it takes into account the effect of the expression involved, is surely not a definitional test; as already noted it tends to become ad hoc balancing. Nor is the rule that suppression is "preferable to a blood bath," in the case of provocative speech before a hostile audience, definitional in nature. Moreover, an important element of

the state asserts," that is, "whether the harm the state is seeking to avert is one that grows out of the fact that the defendant is communicating . . . or rather would arise even if the defendant's conduct had no communicative significance whatsoever." Id. at 1497. This approach, in separating out the "communicative" aspect of conduct, seems inconsistent with Ely's insistence that "burning a draft card to express opposition to the draft is an undifferentiated whole, $100 \%$ action and $100 \%$ expression." Id. at 1495, 1496. Moreover, there would always seem to be a "causal connection" between the communication (mcluding the form in which it is embodied) and the harm the state seeks to avert; otherwise there would be no first amendment problem. In any event, Ely, like Tribe, does not meet the objection that the basic issue goes to the actual effect of the government regulation on expression-whether it "abridges" freedom of expression-and that the basic first amendment doctrine is that the government cannot achieve other social interests by "abridging" expression. The distinction that both are making seems to be merely one of formwhether the government regulation directly restricts expression in so many words or is on its face addressed to other forms of conduct.

117. L. TRIBE, supra note 2, at 641, 681-82; American Mini Theatres, Inc., 427 U.S. 50; O'Brien, 391 U.S. 367. 
Tribe's argument that certain categories of expression can be excluded from first amendment protection is that the expression involved has no social value. Yet the very essence of first amendment theory is that the government must not be the one to determine the social value of expression. ${ }^{118}$

(4) In track two cases Tribe's emphasis upon allowing restriction of expression where other alternatives are available treads upon very dangerous ground. Numerous restrictions upon expression could be justified on such a basis, creating an ever-narrowing circle of expression that remams free.

(5) The balancing formula in track two cases takes a very circumscribed view of the first amendment interests at stake. It limits thein to two negative considerations: (1) whether the restriction leaves too little breathing space for communicative activity; and (2) whether it leaves too little access to the channels of communication. The positive values sought by the system, including the self-fulfillment value, are left out of the equation. More important, in most cases other than public access cases the government's burden of justification is "minimal." Such a doctrine cannot be characterized even as "balancing."

(6) Tribe takes little account of the dynamics of suppression. Aside from his recognition of the need for "breatlimg space" in track two cases, his formulations pay small heed to the realities of operatimg a system of freedom of expression.

All in all, Tribe's doctrimal structure comes closer to describing the present state of first amendment theory than providing a coherent and effective substitute.

\section{B. Professor Baker's Doctrinal Structure}

Professor Baker has produced one of the most interesting and origmal theories of the first amendinent. Baker, like Tribe, proceeds from the traditional value structure, although he attempts to compress the four functions of a system of freedom of expression into two: self-fulfillment and participation in social change. Like Scanlon, he justifies protecting these values in terms of the rights of the individual witlim the collective:

Obligation exists only in relationships of respect. To justify legal obligation, the community inust respect individuals as equal, rational and autonomous inoral beings. For the community legitimately to expect individuals to respect collective decisions, i.e., legal rules, the community must respect the dignity and equal worth of its members. ${ }^{119}$

118. L. TRIBE, supra note 2, at 620,671-72.

119. Baker, supra note 2, at 991 . Baker's discussion of the value structure appears at 990-92. 
Baker's rules for determining the scope of first amendment protection flow from the value structure. He recognizes, however, that not all conduct that promotes one of his designated values is covered by the first amendment. Baker does not attempt to solve this problem by defining a category of conduct designated speech, or expression, or commumication, and distinguishing such behavior from action or other conduct. Like Tribe, he specifically rejects the expression-action dichotomy. Rather, he undertakes to construct the rules for the protection of "speech" without attempting to define it, and then includes within this structure of protected speech all "action" or "nonverbal" conduct that serves the same functions as "speech." 120

In Baker's view, the key to determining whether conduct should be protected under the first amendment lies in the method, or manner, by which the "speech," verbal and nonverbal, promotes the values underlying the system of freedom of expression. He would restrict the "speech" that should be protected to conduct that is not physically violent or destructive - that is, not "coercive." This does not mean that no "speech" that results in harm or harmful actions may be protected. When harms "occur only to the extent people 'mentally' adopt perceptions or attitudes," the "speech" from which the harms result should remaim protected. Such speech does not interfere with another's legitimate "decision authority" because it does not take the form of "destruction of another's property or coercing another's behavior." Indeed, pumishinent of speech under these circumstances would denigrate "the responsibility and freedom of the listener." In sum:

Both the concept of coercion and the rationale for protecting speech draw from the same ethical requirement that the integrity and autonomy of the individual moral agent must be respected. Coercive acts typically disregard the ethical principle that, in interactions with others, one must respect the other's autonoiny and integrity as a person. When trying to influence another person, one must not disregard that person's will or the integrity of the other person's mental processes. The type of speech that manifestly disregards the other's will or the integrity of the other's mental processes is not protected. Thus, the pohitical morahity summed up by the first amendment requires protection for speech that manifests or contributes to the speaker's values or visions-speech which furthers the two key first amendment values of self-fulfillment and participation in change-as long as the speech does not involve violence to or coercion of another. ${ }^{121}$

More specifically, Baker concludes that there are "three types of speech properly subject to positive law control." They are: "1) speech involved in an actual or attempted taking or physical injury to an-

120. Id. at $997,1009-12$.

121. Id. at 1001-02. The quotations in the preceding paragraph are at $998,997$. 
other's person or property; 2) speech designed to disrespect and distort the integrity of another's mental processes; 3) speech not chosen by the speaker and which, therefore, cannot be attributed to the speaker's manifestation of her substantive values." Participation in a bank robbery by contributing information concerning the layout of the bank is an example of the first category, blackmail of the second, and commercial spcech of the third. ${ }^{122}$

Baker then goes on to argue that first amendment protection should be extended to "action," or "nonverbal conduct," where such conduct "furthers key first amendment values," where protection is "essential for adequate realization of those values," where the conduct promotes such values "in a relevantly similar manner" to protected speech conduct, and where "primcipled lines can identify which conduct should be protected in what ways." Obviously the last criterion raises the most difficulties, but Baker's elaborate and, to me, somewhat obscure rules for drawing this line need not be considered here. ${ }^{123}$

Taken as a whole, Baker's formulations offer inportant insights and ideas. His main point-that the manner in which speech affects others is the key to whether it should be protected or not-goes to the heart of first amendment theory. It is im these terms that the preferred position for expression is to be justified and must be implemented. Moreover, Baker's view of "coercion" as marking the line between protected and unprotected speech is a major contribution to the development of first amendment doctrime. The concept of "coercive speech" is a valuable tool in delineatimg the borders of the system of freedom of expression. Finally, Baker's approach focuses on a central feature in the construction of a system for the constitutional protection of minority rights: the kind of "harms" that a majority may be asked to accept and the reasons for asking it to do so.

Nonetheless, there are problems with Baker's proposed structure:

(1) Although he purports to accept the traditional values underlymg the system of freedoun of expression, Baker frames his whole structure in terms of individual liberty to the exclusion of social advantage. This tends to set individual rights agamst collective rights im a zero-sum game. Moreover, it sacrifices much of the existimg ideological, political, and legal force behind the traditional system, which justifies freedoun of expression partly in terms of the promotion of the social good. It is as if Adam Smith had left "the mvisible hand" out of his system of laissez-faire economics.

(2) The basic guidelines for the courts to follow are exceedingly

122. Id. at 1002 .

123. Id. at 1009 . 
vague. The critical issue for decision is what constitutes "coercion." It is not clear how the courts would resolve this question in many contexts, mcluding defamation, privacy, and free press-fair trial cases.

(3) Baker's formulations fail to take into account the dynamics of maintaining a system of freedom of expression. Thus, there might be situations where it would be important to permit even "coercive" speech in order to allow "breathing space"-that is, to allow the system to work. Baker's failure to deal with these matters may stem froin the fact that he does not visualize freedom of expression as a system at all.

(4) Extension of Baker's structute into the area of "action" tends to blur the perimeters of the system. This may, in turn, lead to a breakdown of tight controls over governmental intervention in the system. The more the courts are asked to move their concept of "speech" away from a colninon sense, intuitional judgment as to what is expression, the harder it is to draw precise lines or to exact adherence to them. There is serious danger that so extending constitutional protection will render the "preferred position" rule-the basis of, the first amendment-meaningless.

(5) The more specific doctrines proposed by Baker fail to address certain hard problems. For example, at what poimt does speech become "involved" in physical injury to another person? This is the kind of issue that must be resolved by resorting to the traditional tests: clear and present danger, ad hoc balancing, or the expression-action dichotomy. Even more open-ended is the question whether certain speech is "designed to disrespect and distort the integrity of another's mental processes." Expression by anyone holding economic power over another might be so characterized, and hence opened to restriction. And "speech not chosen by the speaker" could conceivably include some speech by pohticians, government employees, or staff members of an organization-expression that clearly should be protected.

Altogether, while Baker has made significant progress, his proposals are not sufficiently conclusive to justify abandoning the quest for other solutions to the problem of formulating first amendment doctrine.

\section{Full Protection Revisited}

\section{The Expression-Action Dichotomy}

The full protection doctrime has been set forth in detail elsewhere, and will not be elaborated here. In essence, it derives from the very nature of the system of freedom of expression. The central principle of the system is that there are certain kinds of conduct that serve special functions in our society and are therefore entitled to special protection, 
primarily from interference by the government. The first and basic step im formulating any first amendment doctrime should be to determme what that conduct is. Roughly, the conduct to be protected is "expression," as distinct from what may be equally roughly termed "action." Where conduct has strong elements of both expression and action, the analytic problem is to determine which predommates. If expression is the dominant element, the conduct is entitled to the special protection conferred by the first amendment. If action is dominant, the conduct is not so protected, although it is entitled to the protection of due process, equal protection, and other constitutional safeguards.

The principal objection to the expression-action dichotomy has been that, smce the conduct to be protected almost always consists of both speech and action-verbal as well as nonverbal conduct-the category to be protected cannot be defined in terms of one or the other. Hence, a determination that certam conduct is expression rather than action is simply a conclusion, reached on mdependent grounds, that the conduct should be protected. Other cominentators go further and argue that there is no distmction between expression and action, but that there are only "expressive acts." 124

The criticism might be justified if the attempt being made were to frame a definition im strictly literal terms of "verbal" as opposed to "nonverbal" conduct, or simply im a loose sense of "expressing" rather than "domg." The expression-action dichotomy is, of course, not that smiple. It attempts to formulate a definition of the kind of conduct that merits special protection under the first amendment. The classification is to be made on the basis of certam characteristics of the conduct in question, mcluding:

(1) Whether the conduct is intended to cominunicate information, ideas, or emotions.

(2) Whether the conduct promotes the set of values underlymg the system of freedom of expression.

(3) The nature of the impact of the conduct upon other persons, particularly whether the impact is essentially mental rather than physical, noncoercive rather than violent, and of a character which it is reasonable to ask a democratic society seeking orderly change to endure.

(4) Whether, although the conduct may not in itself qualify for special protection, such protection is necessary in order to safeguard other, qualified conduct.

(5) Other factors that may be discovered or articulated as the

124. See id. at 1009-12; L. TRIBE, supra note 2, at 598-601; Yacavone, Emerson's Distinction, 6 ConN. L. Rev. 49 (1973); BeVier, supra note 11, at 319-20. See also DuVal, supra note 2, at 18286; Scanlon, supra note 2, at 207-08. 
concept develops. ${ }^{125}$

It is hardly "illogical" or "impractical" to address the problem in these terms. If conduct that is to receive special protection under the first amendment cannot be defined, then there would be no sense to what Milton, Mill, Meiklejohn, and others have been saying over the centuries, and the whole structure of the first amendment would collapse. Surely a broad class of human conduct can be defined that basically deals with mental as distinct from physical matters, has a different impact on others, serves a different purpose, and should for some purposes be treated differently from other conduct. Although it may not always be simple to implement, such a concept is at least firm enough to serve as the foundation upon which to build a system of freedom of expression.

It is true that, in some cases, the determination that particular conduct deserves special protection is not easily made. The problem may be to locate the conduct on a spectrum ranging from "pure expression" to "pure action." But this is not as difficult as the critics suggest. Most of the conduct that calls for decision in a system of freedom of expression falls near one end of the spectrum or the other. In practice, probably ninety-five percent of the conduct for which special protection is claimed under the first amendment is clearly "expression" and there is no dispute as to how to classify it. In doubtful cases, near the middle of the spectruin, resort must be had to the extrimsic points of reference found in the basic structure of the system, as outhined above. ${ }^{126}$

A second objection to the expression-action approach has been that one cannot derive a definition of expression from the values underlying the system because other forms of conduct also promote the same values. This criticism would be well taken if the basic value structure of the system were the only point of reference. It is not, however, the sole basis for determining what kind of conduct is to be given special proteçtion; other characteristics of the conduct must also be taken into account. Here Baker has made a significant contribution by focusing on how the conduct affects others. And he has made an equally substantial contribution in emphasizing the importance of whether the conduct is "coercive." 27

A third criticism is that the expression-action approach does not

125. For a more complete analysis, see General THEORY, supra note 1, at 60-61; SYSTEM, supra note 1 , at 17-18, 21-22, 58-59, 75, 80-81, 83-85, 124-26 passim.

126. Of the 60 or so major first amendment cases decided by the Supreme Court during the 10 terms from 1969 to 1979 , I count only two that raised any serious issue as to whether the conduct sought to be protected constituted "expression" or not. These are the two flag desecration cases, Smith v. Goguen, 415 U.S. 566 (1974), and Spence, 418 U.S. 405.

127. For statements of the criticism, see Baker, supra note 2, at 1010; Bork, supra note 11, at 25-28. 
provide a "principled" basis for judicial review. The argument is advanced primarily by those who would confine the scope of first amendment protection to "political speech." In their view, courts cannot undertake to protect other forms of expression without making judgments on grounds of wisdom or expediency rather than "neutral principles." The criticism is premised on an artificially narrow view of "primciple." Under this view, the only appropriate bases for judgment in first amendment cases are rules directly derived from the specific intent of the framers of the first amendment, as revealed by its text and history. Our tradition of judicial review, perhaps the most important institution for safeguarding individual rights, has never been so sharply circumscribed. Nor should it be, for the result would be a highly abridged system of freedom of expression. Moreover, it is difficult to reconcile this limited view of a court's proper function with the openended balancing test employed by inost of those who take the "neutral primciples" approach. ${ }^{128}$

In one way or another, all these critics of the expression-action dichotony say that a definitional approach to first amendment imterpretation is not possible. If that were so, then the only alternative would seein to be ad hoc balancing. There is nothing inherent in the problems of the systein of freedom of expression, however, that coinpels acceptance of either that criticism or its implications.

\section{2. "Full" Protection}

Having determined what conduct is to be covered by the first amendment, a comprehensive doctrime must next determine what degree of protection that conduct should receive. Expression-action analysis does not, without more, suggest that covered conduct should be entitled to "full" protection. However, the language of the first amendment, which prescribes that "no law" may "abridge" freedom of expression, together with the functions and dynamics of the system, the role played by the courts in supporting the system, and other features of the basic structure of the system do lead to that conclusion. As has already been noted, "full" protection is possible only if the category of conduct to be protected is carefully defined. Hence the expression-action dichotomy and realization of the special protection intended for expression are interlocked. In my opinion, a successful systein of freedom of expression cannot be maintained without this approach.

The full protection doctrine, based on the expression-action dichotomy, does not solve all of the problems of the system of freedom of expression; various subsidiary doctrines are essential to round out the

128. See Bork, supra note 11, at 20-21, 26-27; BeVier, supra note 11, at 313-17. 
legal foundations of such a system. And although they cannot be fully discussed here, it is well to keep them in mind. Thus, as noted above, certain kinds of conduct are necessarily excluded from the system because the basic conditions under which they are carried on do not permit freedom of expression to operate in the saine way as in the main system. These include expression by members of the military and by children, as well as, in my judgment, cominercial speech. Other problems relate to the physical place in which the right of expression is exercised, or allocation of scarce physical facilities. These issues call for special rules. Questions of imternal regulation or promotion of the system, not involving a conflict with other kinds of interests, are not solved by the full protection doctrine. The rights of persons in institutions and organizations crcate additional issues. And inuch first amendment doctrine, such as the overbreadth rule and the doctrine forbidding prior restraint, involves procedural matters. These and other subsidiary doctrines supplement, but cannot replace, a full protection approach. ${ }^{129}$

\section{CONCLUSION}

Broad agreement concerning the basic values that underhe our system of freedom of expression continues to exist. Unfortunately, the quest for effective legal doctrine that would translate those values into reality has not been successful. Cominentators have not been able to devise sufficiently disciplined rules to control the forces and institutions that impair the functioning of the system. Nor has the Burger Court. The general approach of that Court was epitomized by Justice Blackmun in Bigelow v. Virginia, when he wrote for the majority: "Advertising, like all public expression, may be subject to reasonable regulation that serves a legitimate public interest." 130 The outcome has been that freedom of expression has by no means received the special protection to which it is theoretically entitled. Rather, it has been given only a watered-down due process protection. A more rigorous doctrinal framework is imperative if the systein is to survive the stresses that are likely to come.

129. For a discussion of these subsidiary problems, see generally SYSTEM, supra note 1.

130. Bigelow, 421 U.S. at 826 . 